\title{
Predictive Biomarkers for the Ranking of Pulmonary Toxicity of Nanomaterials
}

\author{
Chinatsu Nishida ${ }^{1}$, Hiroto Izumi ${ }^{2}$, Taisuke Tomonaga ${ }^{2}{ }^{(0)}$, Jun-ichi Takeshita ${ }^{3}{ }^{(0)}$, \\ Ke-Yong Wang ${ }^{4}$, Kei Yamasaki ${ }^{1}$, Kazuhiro Yatera ${ }^{1} \mathbb{D}$ and Yasuo Morimoto ${ }^{2, * \mathbb{D}}$ \\ 1 Department of Respiratory Medicine, University of Occupational and Environmental Health, Japan. \\ 1-1 Iseigaoka, Yahata-nishi-ku, Kitakyushu, Fukuoka 807-8555, Japan; c-nishi@med.uoeh-u.ac.jp (C.N.); \\ yamasaki@med.uoeh-u.ac.jp (K.Y.); yatera@med.uoeh-u.ac.jp (K.Y.) \\ 2 Department of Occupational Pneumology, Institute of Industrial Ecological Sciences, University of \\ Occupational and Environmental Health, Japan. 1-1 Iseigaoka, Yahata-nishi-ku, Kitakyushu, \\ Fukuoka 807-8555, Japan; h-izumi@med.uoeh-u.ac.jp (H.I.); t-tomonaga@med.uoeh-u.ac.jp (T.T.) \\ 3 Research Institute of Science for Safety and Sustainability, National Institute of Advanced Industrial Science \\ and Technology (AIST), Tsukuba, Japan. 16-1 Onogawa, Tsukuba, Ibaraki 305-8569, Japan; \\ jun-takeshita@aist.go.jp \\ 4 Shared-Use Research Center, University of Occupational and Environmental Health, Japan. 1-1 Iseigaoka, \\ Yahata-nishi-ku, Kitakyushu, Fukuoka 807-8555, Japan; kywang@med.uoeh-u.ac.jp \\ * Correspondence: yasuom@med.uoeh-u.ac.jp; Tel.: +81-93-691-7136
}

Received: 3 September 2020; Accepted: 9 October 2020; Published: 15 October 2020

check for updates

\begin{abstract}
We analyzed the mRNA expression of chemokines in rat lungs following intratracheal instillation of nanomaterials in order to find useful predictive markers of the pulmonary toxicity of nanomaterials. Nickel oxide $(\mathrm{NiO})$ and cerium dioxide $\left(\mathrm{CeO}_{2}\right)$ as nanomaterials with high pulmonary toxicity, and titanium dioxide $\left(\mathrm{TiO}_{2}\right)$ and zinc oxide $(\mathrm{ZnO})$ as nanomaterials with low pulmonary toxicity, were administered into rat lungs $(0.8$ or $4 \mathrm{mg} / \mathrm{kg} \mathrm{BW})$. $\mathrm{C}-\mathrm{X}-\mathrm{C}$ motif chemokine 5 (CXCL5), C-C motif chemokine 2 (CCL2), C-C motif chemokine 7 (CCL7), C-X-C motif chemokine 10 (CXCL10), and C-X-C motif chemokine 11 (CXCL11) were selected using CDNA microarray analysis at one month after instillation of $\mathrm{NiO}$ in the high dose group. The mRNA expression of these five genes were evaluated while using real-time quantitative polymerase chain reaction (RT-qPCR) from three days to six months after intratracheal instillation. The receiver operating characteristic (ROC) results showed a considerable relationship between the pulmonary toxicity ranking of nanomaterials and the expression of CXCL5, CCL2, and CCL7 at one week and one month. The expression levels of these three genes also moderately or strongly correlated with inflammation in the lung tissues. Three chemokine genes can be useful as predictive biomarkers for the ranking of the pulmonary toxicity of nanomaterials.
\end{abstract}

Keywords: biomarker; pulmonary toxicity; chemokine; nanomaterials

\section{Introduction}

Nanoparticles are defined as particles with at least one dimension of $100 \mathrm{~nm}$ or less [1,2] and, in recent years, the demand for industrial nanomaterials composed of these nanoparticles has increased significantly. New industrial nanomaterials are being created one after another by nanotechnology for controlling functions on the nanometer scale, and they are being used for various applications in various fields. The pulmonary toxicity of nanomaterials needs to be fully assessed before the industrial nanomaterials are handled by humans. It is necessary to develop biomarkers in order to predict the hazard level of industrial nanomaterials, because multi-wall carbon nanotubes (MWCNTs), a representative nanomaterial, are known to be carcinogenic: the development 
of lung tumors or malignant pleural mesothelioma was confirmed in intratracheal instillation $[3,4]$ and in inhalation studies [5].

In pulmonary disorders that are caused by respirable chemicals, it is considered that the chemical deposits in the lungs cause sustained inflammation and ultimately the formation of chronic and irreversible lesions, such as lung fibrosis and tumors [6-10]. It has been reported, for example, that asbestos and crystalline silica, which have high pulmonary toxicity, cause sustained inflammation in the lungs, leading to irreversible fibrosis, lung cancer and mesothelioma [11,12]. Thus, sustained inflammation is considered to be an important process in the induction of chronic and irreversible lesions of the lung [6-10,13]. MWCNTs, which are carcinogenic, have shown sustained inflammation in the lung following inhalation and intratracheal instillation [14-17]. Taken together, it is thought that 'sustained inflammation' is an important process in predicting lung disorders that are caused by industrial nanomaterials. It is considered that the detection of biomarkers that reflect sustained inflammation in the lung can lead to early detection of the hazardous effects of nanomaterials and, thus, can predict the progression to chronic/irreversible lesions. Sustained inflammation is composed of neutrophils and alveolar macrophages, and its pathogenesis is thought to be associated with cytokines, especially chemokines $[6,9,18]$.

In this study, we focused on inflammation-related genes that are based on the results of a comprehensive gene expression analysis using cDNA microarray, and examined whether or not biomarkers for predicting lung disorder by nanomaterials can be detected following the intratracheal instillation of nanomaterials with different pulmonary toxicities.

\section{Materials and Methods}

\subsection{Sample Nanomaterials}

We used nickel oxide $(\mathrm{NiO})$, cerium dioxide $\left(\mathrm{CeO}_{2}\right)$, titanium dioxide $\left(\mathrm{TiO}_{2}\right)$, and zinc oxide $(\mathrm{ZnO})$ as industrial nanomaterials in the present study. Commercially available $\mathrm{NiO}$ (US3355, US Research Nanomaterials, Houston, TX, USA), $\mathrm{CeO}_{2}$ (Wako Chemical, Ltd., Osaka, Japan), $\mathrm{TiO}_{2}$ (Rutile) (MT-150AW, Teyca Co. Ltd., Osaka, Japan), and ZnO (Sigma-Aldrich Co. LLC., Tokyo, Japan) were dispersed in $0.4 \mathrm{~mL}$ distilled water. Table 1 shows the physicochemical profiles of these samples [19-24]. Transmission electron microscope (TEM) images of each four nanoparticle suspension are shown in our previous reports $[20,21,24]$. We defined the toxicity of the chemicals, as follows: the chemicals that induced either sustained inflammation, fibrosis, or tumors were set as having high pulmonary toxicity, and the chemicals that did not induce any of those pathological lesions were set as having low pulmonary toxicity. Accordingly, $\mathrm{NiO}$ and $\mathrm{CeO}_{2}$ were classified as nanomaterials with high pulmonary toxicity $[10,19,20,25,26]$, and $\mathrm{TiO}_{2}$ and $\mathrm{ZnO}$ were classified as nanomaterials with low pulmonary toxicity $[19,21,27-29]$.

Table 1. Physiochemical characterization of the nanomaterials used in the present study.

\begin{tabular}{ccccc}
\hline Nanomaterials & $\mathrm{NiO}$ & $\mathrm{CeO}_{2}$ & $\mathrm{TiO}_{2}$ & $\mathrm{ZnO}$ \\
\hline Pulmonary toxicity & $\mathrm{High}$ & $\mathrm{High}$ & Low & Low \\
\hline Primary diameter & $19 \mathrm{~nm}$ & $7.8 \mathrm{~nm}$ & $\begin{array}{c}\text { Short } 12 \mathrm{~nm} \\
\text { Long } 55 \mathrm{~nm}\end{array}$ & $35 \mathrm{~nm}$ \\
\hline $\begin{array}{c}\text { Specific surface } \\
\text { area }\end{array}$ & $57 \mathrm{~m}^{2} / \mathrm{g}$ & $101 \mathrm{~m}^{2} / \mathrm{g}$ & $111 \mathrm{~m}^{2} / \mathrm{g}$ & $31 \mathrm{~m}^{2} / \mathrm{g}$ \\
\hline Shape & Sphere & Irregular shape & Spindle-shaped & Sphere like \\
\hline $\begin{array}{c}\text { Secondary } \\
\text { diameter (DLS) }\end{array}$ & $39.8-47.1 \mathrm{~nm}$ & $2.6-9.3 \mathrm{~nm}$ & $20-80 \mathrm{~nm}$ & $17-37 \mathrm{~nm}$ \\
\hline Purity & More than $99.5 \%$ & $99.9 \%$ & $99.5 \%$ & $99.9 \%$ \\
\hline Bulk density & $6.72 \mathrm{~g} / \mathrm{cm}^{3}$ & $7.22 \mathrm{~g} / \mathrm{cm}^{3}$ & $4.17 \mathrm{~g} / \mathrm{cm}^{3}$ & $5.60 \mathrm{~g} / \mathrm{cm}^{3}$ \\
\hline Solubility & Low $\left(>\mathrm{CeO}_{2}\right)$ & Low & Low & High \\
\hline
\end{tabular}

Primary particle diameter: the particle diameter of the one particle; Secondary particle diameter: the particle diameter of agglomerate; DLS: Dynamic light scattering. 


\subsection{Animals}

Male Fischer 344 rats (9-11 weeks old) that were used for exposure to nanomaterials were purchased from Charles River Laboratories International, Inc., Kanagawa, Japan. The animals were kept in the Laboratory Animal Research Center of the University of Occupational and Environmental Health for two weeks with free access to a commercial diet and water. All of the procedures and animal handling were done according to the guidelines that were described in the Japanese Guide for the Care and Use of Laboratory Animals were approved by the Animal Care and Use Committee, University of Occupational and Environmental Health, Japan (animal studies ethics clearance proposal number; AE11-012).

\subsection{Intratracheal Instillation}

The $\mathrm{NiO}, \mathrm{CeO}_{2}, \mathrm{TiO}_{2}$, and $\mathrm{ZnO}$ nanomaterials were suspended in $0.4 \mathrm{~mL}$ distilled water. Doses of $0.2 \mathrm{mg}$ (low dose, equivalent to $0.8 \mathrm{mg} / \mathrm{kg} \mathrm{BW}$ ) or $1 \mathrm{mg}$ (high dose, equivalent to $4 \mathrm{mg} / \mathrm{kg} \mathrm{BW}$ ) were administered to rats (12 weeks old) in a single intratracheal instillation. Each of the negative control groups received distilled water.

\subsection{Animals Following Intratracheal Instillation}

In the exposure to the four different nanomaterials and the negative control, there were five rats in each group at each time point. The animals were dissected at three days, one week, one month, three months, and six months after intratracheal instillation and the lung was divided into right and left lungs. Analysis of cDNA microarray and qRT-PCR was performed with the homogenized third lobe of the right lung, and histopathological evaluation was performed with the left lung inflated and fixed by $4 \%$ paraformaldehyde or $10 \%$ formaldehyde.

\subsection{Total RNA Extraction}

The third lobes of the right lungs ( $n=5$ per group per time point) were homogenized while using a QIAzol lysis reagent with a TissueRupotor (Qiagen, Hilden, Germany). Total RNA from the homogenates was extracted using a miRNeasy Mini Kit (Qiagen, Hilden, Germany) following the manufacturer's instructions. RNA was quantified while using a NanoDrop 2000 spectrophotometer (Thermo Fisher Scientific Inc., Waltham, MA, USA) and the quality of the samples was analyzed by a Bioanalyzer 2100 (Agilent Technologies, Santa Clara, CA, USA).

\subsection{Microarray Analysis}

We used a three-dimensional (3D)-Gene Rat Oligo Chips 20K (version 1.1) (Toray Industries, Tokyo, Japan), which could mount 20,174 genes, for the DNA microarray analysis. Total RNA extracted from the lungs of the five rats in the NiO-high dose group was mixed in equal amounts to make one sample, and that was amplified by the use of an Amino Allyl MessageAmp II aRNA Amplification Kit (Ambion, Inc., Austin, CA, USA). The negative control group was treated in the same manner. The antisense RNA (aRNA) were labeled with Cy5, using Amersham Cy5 Mono-Reactive Dye (GE Healthcare, Buckinghamshire, UK), and the labeled aRNA were hybridized at $37^{\circ} \mathrm{C}$ for $16 \mathrm{~h}$. The hybridization was performed according to the supplier's protocols [30]. The chips were washed and dried, and then scanned in an ozone-free environment while using a 3D-Gene Scanner 3000 (Toray Industries, Tokyo, Japan) and analyzed by use of 3D-Gene Extraction Software (Toray Industries, Tokyo, Japan). The digitalized fluorescent signals provided by the above-described software were regarded as the raw data. All of the normalized data were globally normalized per microarray, such that the median of the signal intensity was adjusted to 25 . The function of the enhanced expression genes was analysed by the Database for Annotation Visualization and Integrated Discovery 6.8 [31]. 


\subsection{Validation of Gene Expression Data Using Quantitative Real-Time Polymerase Chain Reaction}

qRT-PCR was performed, as described previously [32]. Briefly, the total RNA extracted from the lungs at each observation point in each group were transcribed into cDNA (High-Capacity cDNA $^{\text {TM }}$ Kit, Life Technologies, Tokyo, Japan). qRT-PCR assays were performed while using TaqMan (TaqMan Gene Expression Assays, Thermo Fisher Scientific Inc., Waltham, MA, USA) according to the manufacturer's protocol. Gene expression data were analyzed by the comparative cycle time $(\Delta \Delta \mathrm{CT})$ method while using the 7500 Fast Real-Time PCR System. The Assays-on-Demand TaqMan probes and primer pairs were CXCL5 (Assay ID Rn00573587_g1), CCL2 (Assay ID Rn00580555_m1), CCL7 (Assay ID Rn01467286_m1), CXCL10 (Assay ID Rn00594648_m1), and CXCL11 (Assay ID Rn00788261_g1). All of the experiments were performed in a StepOnePlus ${ }^{\mathrm{TM}}$ Real-Time PCR Systems (Life Technologies, Tokyo, Japan). All of the expression data were normalized to endogenous control $\beta$-actin expression (Assay ID Rn00667869_m1).

\subsection{Statistical Analysis}

Statistical analysis was carried out using JMP ${ }^{\circledR}$ Pro software (JMP Version 14.2.0, SAS Institute Inc., Cary, NC, USA). $p$ values $<0.05$ were considered to be significant. Dunnett's tests were used appropriately in order to detect individual differences in the gene expression levels of each of the 5 chemokines between those exposed to the four nanomaterial samples and the negative controls. We assigned the toxicity of the exposure nanomaterials as being high or low according to the gene expression levels of each of the five chemokines of each sample (20 samples for both high and low toxicity at each time point), and analyzed the sensitivity and specificity for high toxicity at each time point to create the receiver operating characteristic (ROC) curves and AUCs. Youden's Index was used in order to determine the cut-off value. Youden's Index was defined, as follows: Youden's Index = sensitivity + specificity-1, where the definitions of sensitivity and specificity are shown in Appendix A Table A1, together with specific examples using a confusion matrix. In the evaluation using the combination of chemokine genes, the cases where the expression of at least one gene was equal to or higher than the cut-off value were defined as positive. Spearman's rank correlation coefficient was used in order to estimate the correlation between gene expression levels of CXCL5, CCL2, CCL7, CXCL10, or CXCL11 and the score of inflammatory cell infiltration of lung tissue.

\subsection{Histopathology and Immunohistochemistry}

The obtained lung tissue, which was inflated and fixed with $4 \%$ paraformaldehyde or $10 \%$ formaldehyde under a pressure of $25 \mathrm{~cm}$ water, was embedded in paraffin, sectioned at a thickness of $4 \mu \mathrm{m}$, and then stained with hematoxylin and eosin (H\&E). The slides were assessed for histological changes (H\&E stain) by a board-certified pathologist (New Histo. Science Laboratory Co., Ltd., Tokyo, Japan). The severity of the histological changes in the lung in the negative control and nanoparticle-exposed rats was scored as none (0), minimal (0.5), mild (1), moderate (2), or severe (3).

The upregulation of CXCL5, CCL2, and CCL7 was evaluated by immunostaining with rabbit anti-mouse CXCL5 polyclonal antibody (1:200 dilution, bs-2549R; Bioss Inc., Woburn, MA, USA), goat anti-rat CCL2 polyclonal antibody (1:200 dilution, sc-1785; Santa Cruz Biotechnologies, Inc., Dallas, CA, USA), and goat anti-mouse CCL7 polyclonal antibody (1:50 dilution, sc-21202; Santa Cruz Biotechnologies, Inc., Dallas, CA, USA), respectively, while using the lung tissue samples from the NiO-high dose group of one month after intratracheal instillation.

\section{Results}

\subsection{Gene Expression Analysis}

Table 2 shows the results of gene expression in the NiO-high dose group by cDNA microarray at one month after intratracheal instillation. The number of genes whose expression was increased eight times or more was 16 (Table $2 \mathrm{~A}$ ), and 5 genes among them were chemokine genes (C-X-C motif 
chemokine 5 (CXCL5), C-C motif chemokine 2 (CCL2), C-C motif chemokine 7 (CCL7), C-X-C motif chemokine 10 (CXCL10), and C-X-C motif chemokine 11 (CXCL11)) (Table 2B). Figure 1 and Appendix A Table A2 show the validated expression levels of the five chemokine genes induced by the four nanomaterials following intratracheal instillation using qRT-PCR over the observation time. The gene expression of CXCL5 in the lung tissue that was exposed to $\mathrm{NiO}$ and $\mathrm{CeO}_{2}$, which have high pulmonary toxicity, was persistently high as compared with the negative control throughout the observation time, while the expression was increased transiently or not increased in the lung tissue exposed to $\mathrm{TiO}_{2}$ and $\mathrm{ZnO}$, which have low pulmonary toxicity, during the observation time. The nanomaterials with high pulmonary toxicity induced persistent expression patterns of the CXCL5 gene during the observation period, and the nanomaterials with low pulmonary toxicity did not, or had transient patterns during the observation period.

Table 2. (A) Number of genes by mRNA expression level in the NiO-high dose group at one month. (B) Description of the genes that are related to 'inflammatory response' among the 16 genes upregulated $\geqq 8$-fold.

\begin{tabular}{ccc}
\hline \multicolumn{2}{c}{ (A) } & \\
\hline & mRNA Level & Number of Genes \\
& (Fold Change of Control) & 450 \\
Up regulation & $\geqq 2$-fold & 383 \\
& $2-4$-fold & 51 \\
& $4-8$-fold & 16 \\
Down regulation & $\geqq 8$-fold & 388 \\
& $\leqq 1 / 2$-fold & 359 \\
& $1 / 2-1 / 4$-fold & 15 \\
& $1 / 4-1 / 8$-fold & 14 \\
\hline
\end{tabular}

(B)

\begin{tabular}{ccc}
\hline Gene Symbol & Gene Description & Fold Change \\
\hline CXCL5 & Chemokine (C-X-C motif) ligand5 & 12.83 \\
CCL2 & Chemokine (C-C motif) ligand2 & 17.93 \\
CCL7 & Chemokine (C-C motif) ligand7 & 23.44 \\
CXCL10 & Chemokine (C-X-C motif) ligand10 & 16.42 \\
CXCL11 & Chemokine (C-X-C motif) ligand11 & 16.70 \\
\hline
\end{tabular}

Table 2 (A) shows the number of genes by mRNA expression level in the NiO-high dose group at one month after intratracheal instillation among 20,174 genes examined using cDNA microarray. (B) There were five genes related to inflammation of the 16 genes in the analysis using Database for Annotation Visualization and Integrated Discovery 6.8 (DAVID 6.8, https://david.ncifcrf.gov).

The expression patterns of CCL2 and CCL7 also showed a similar tendency to CXCL5. CCL2 genes had a significantly persistent increase in the $\mathrm{NiO}$ and $\mathrm{CeO}_{2}$ high dose groups, and CCL7 genes had a significantly persistent increase in the $\mathrm{NiO}$ high dose group. Both of the genes had an insignificant increase in the $\mathrm{NiO}$ and $\mathrm{CeO}_{2}$ low dose groups and in the $\mathrm{CeO}_{2}$ high dose group. There was a transient increase in the $\mathrm{TiO}_{2}$ and $\mathrm{ZnO}$-exposed groups at three days or one month following intratracheal instillation.

On the other hand, the gene expression of CXCL10 and CXCL11 in the NiO and ZnO-exposed groups increased transiently at three days or one week or one month following intratracheal instillation, and no difference was observed in the expression level between nanomaterials of high and low pulmonary toxicity. 

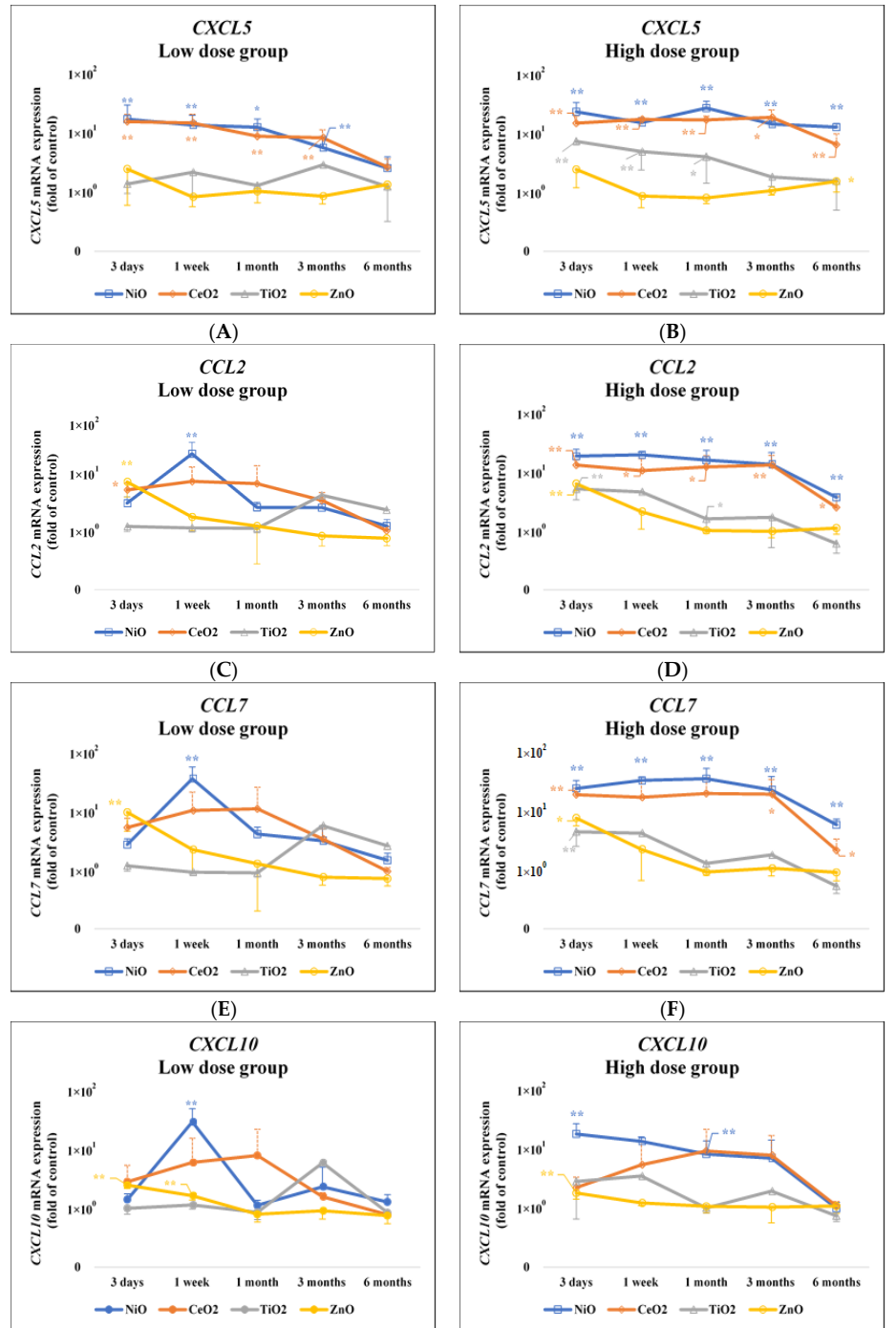

(G)
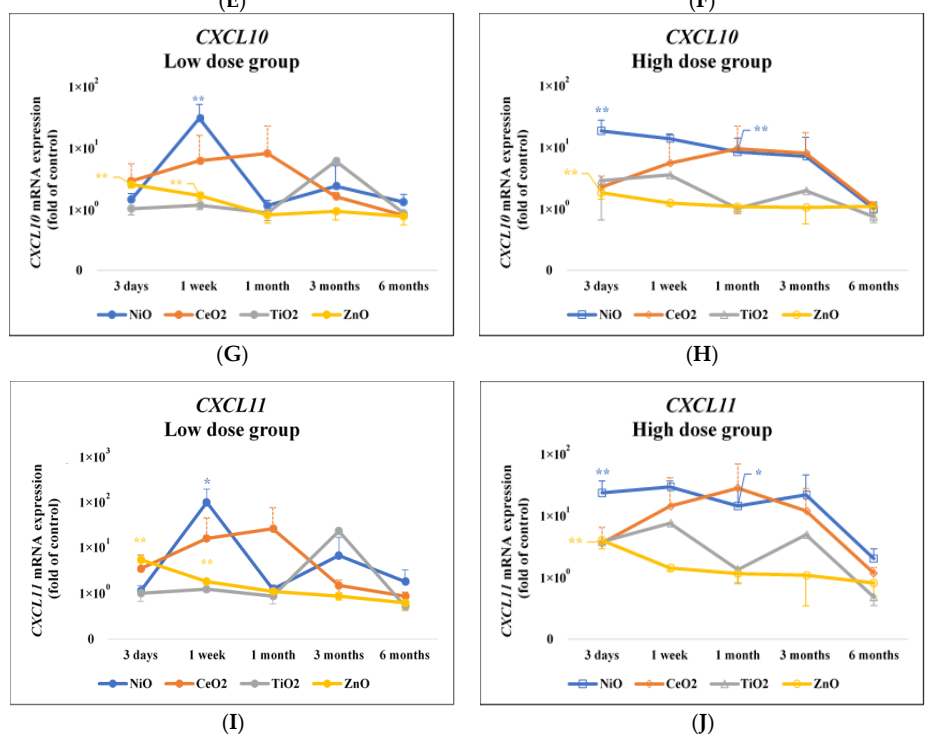

Figure 1. Gene expression of five chemokines in lung exposed to nanomaterials with different pulmonary toxicities. (A)CXCL5 mRNA expression (Low dose group); (B) CXCL5 mRNA expression (High dose group); (C) CCL2 mRNA expression (Low dose group); (D) CCL2 mRNA expression (High dose group); (E) CCL7 mRNA expression (Low dose group); (F) CCL7 mRNA expression (High dose group); (G) CXCL10 mRNA expression (Low dose group); (H) CXCL10 mRNA expression (High dose group); (I) CXCL11 mRNA expression (Low dose group); (J) CXCL11 mRNA expression (High dose group). Data, normalized to $\beta$-actin endogenous control, are presented as fold change relative to the negative controls (distilled water). Values changes are mean \pm standard deviation (SD) $(p<0.05$, $n=5)$. Increased expression of $C X C L 5$ gene in the $\mathrm{NiO}$ and $\mathrm{CeO}_{2}$ groups was persistently higher, and that in the $\mathrm{TiO}_{2}$ and $\mathrm{ZnO}$ groups transiently higher compared with the negative control groups, respectively. CCL2 and CCL7 also showed a similar tendency to CXCL5 (* $p<0.05$, ${ }^{* *} p<0.01$ ). The low dose groups: $0.2 \mathrm{mg}$; the high dose groups: $1.0 \mathrm{mg}$. Value of approximate $1 \times 10^{0}$ means the negative control. 


\subsection{Assessment of the Accuracy of Gene Expression of the Toxicity of Chemicals}

Table 3 shows the results of the receiver operating characteristics (ROC) for the toxicity of the nanomaterials by the gene expression. Recognizing $\mathrm{NiO}$ and $\mathrm{CeO}_{2}$ as substances with high pulmonary toxicity and $\mathrm{TiO}_{2}$ and $\mathrm{ZnO}$ as substances with low pulmonary toxicity, we examined whether or not this pulmonary toxicity ranking was related to the expression of the five chemokine genes. The maximum areas under the curves (AUC) of each gene were generally observed at one week and one month following intratracheal instillation. There was a considerable relationship between the pulmonary toxicity of the nanomaterials and the gene expression of CXCL5, CCL2, and CCL7, with AUC of 0.95 or higher at one week and one month. Further, false negatives could be minimized when evaluated with the combination of CXCL5, CCL2, and CCL7 (Table 4). On the other hand, there seemed to be a relatively low relationship between the pulmonary toxicity of the nanomaterials and gene expressions of CXCL10 and CXCL11 during the other observation times.

Table 3. Receiver operating characteristic (ROC) analysis between gene expression and pulmonary toxicity of nanomaterials.

\begin{tabular}{|c|c|c|c|c|c|}
\hline $\begin{array}{c}\text { Observation } \\
\text { Time }\end{array}$ & 3 Days & 1 Week & 1 Month & 3 Months & 6 Months \\
\hline & $\begin{array}{c}\text { AUC } \\
\text { (95\% C.I.) } \\
\text { (Cut-off Value) }\end{array}$ & $\begin{array}{c}\text { AUC } \\
\text { (95\% C.I.) } \\
\text { (Cut-off Value) }\end{array}$ & $\begin{array}{c}\text { AUC } \\
\text { (95\% C.I.) } \\
\text { (Cut-off Value) }\end{array}$ & $\begin{array}{c}\text { AUC } \\
\text { (95\% C.I.) } \\
\text { (Cut-off Value) }\end{array}$ & $\begin{array}{c}\text { AUC } \\
\text { (95\% C.I.) } \\
\text { (Cut-off Value) }\end{array}$ \\
\hline CXCL5 & $\begin{array}{c}0.990 \\
(0.982-0.999) \\
(10.008)\end{array}$ & $\begin{array}{c}0.998 \\
(0.961-1.000) \\
(10.308)\end{array}$ & $\begin{array}{c}0.995 \\
(0.948-1.000) \\
(9.513)\end{array}$ & $\begin{array}{c}0.983 \\
(0.874-0.998) \\
(3.277)\end{array}$ & $\begin{array}{c}0.928 \\
(0.803-0.976) \\
(1.934))\end{array}$ \\
\hline CCL2 & $\begin{array}{c}0.693 \\
(0.501-0.835) \\
(11.495)\end{array}$ & $\begin{array}{c}0.973 \\
(0.841-0.996) \\
(3.919)\end{array}$ & $\begin{array}{c}0.980 \\
(0.904-0.996) \\
(1.945)\end{array}$ & $\begin{array}{c}0.910 \\
(0.753-0.971) \\
(2.059)\end{array}$ & $\begin{array}{c}0.848 \\
(0.674-0.937) \\
(1.076)\end{array}$ \\
\hline CCL7 & $\begin{array}{c}0.680 \\
(0.487-0.826) \\
(12.380)\end{array}$ & $\begin{array}{c}0.968 \\
(0.860-0.993) \\
(5.090)\end{array}$ & $\begin{array}{c}0.993 \\
(0.933-0.999) \\
(1.990)\end{array}$ & $\begin{array}{c}0.898 \\
(0.744-0.963) \\
(2.007)\end{array}$ & $\begin{array}{c}0.893 \\
(0.720-0.964) \\
(1.020)\end{array}$ \\
\hline CXCL10 & $\begin{array}{c}0.603 \\
(0.415-0.764) \\
(8.311)\end{array}$ & $\begin{array}{c}0.795 \\
(0.592-0.912) \\
(2.088)\end{array}$ & $\begin{array}{c}0.848 \\
(0.673-0.974) \\
(1.620)\end{array}$ & $\begin{array}{c}0.778 \\
(0.593-0.894) \\
(1.466)\end{array}$ & $\begin{array}{c}0.663 \\
(0.473-0.811) \\
(1.097)\end{array}$ \\
\hline CXCL11 & $\begin{array}{c}0.525 \\
(0.340-0.704) \\
(7.843)\end{array}$ & $\begin{array}{c}0.890 \\
(0.744-0.958) \\
(2.790)\end{array}$ & $\begin{array}{c}0.883 \\
(0.741-0.952) \\
(2.073)\end{array}$ & $\begin{array}{c}0.813 \\
(0.612-0.922) \\
(1.025)\end{array}$ & $\begin{array}{c}0.920 \\
(0.798-0.971) \\
(0.706)\end{array}$ \\
\hline
\end{tabular}

AUC: Area under the curve; $95 \%$ C.I.: $95 \%$ Confidence interval.

Table 4. Sensitivity and specificity of gene expression of five chemokines in the pulmonary toxicity of nanomaterials.

\begin{tabular}{|c|c|c|c|c|c|c|c|c|c|}
\hline & & \multicolumn{2}{|c|}{ Sensitivity } & \multicolumn{2}{|c|}{ Specificity } & \multicolumn{2}{|c|}{ False Positive } & \multicolumn{2}{|c|}{ False Negative } \\
\hline \multirow{6}{*}{3 days } & CXCL5 & 0.95 & $(19 / 20)$ & 1.00 & $(20 / 20)$ & 0.00 & $(0 / 20)$ & 0.05 & $(1 / 20)$ \\
\hline & CCL2 & 0.50 & $(10 / 20)$ & 0.95 & $(19 / 20)$ & 0.05 & $(1 / 20)$ & 0.50 & $(10 / 20)$ \\
\hline & CCL7 & 0.50 & $(10 / 20)$ & 0.95 & $(19 / 20)$ & 0.05 & $(1 / 20)$ & 0.50 & $(10 / 20)$ \\
\hline & CXCL10 & 0.30 & $(6 / 20)$ & 1.00 & $(20 / 20)$ & 0.00 & $(0 / 20)$ & 0.70 & $(14 / 20)$ \\
\hline & CXCL11 & 0.35 & $(7 / 20)$ & 0.95 & $(19 / 20)$ & 0.05 & $(1 / 20)$ & 0.65 & $(13 / 20)$ \\
\hline & CXCL5 + CCL2 + CCL7 & 0.90 & $(18 / 20)$ & 0.05 & $(1 / 20)$ & 0.95 & $(19 / 20)$ & 0.10 & $(2 / 20)$ \\
\hline \multirow{6}{*}{1 week } & CXCL5 & 0.95 & $(19 / 20)$ & 1.00 & $(20 / 20)$ & 0.00 & $(0 / 20)$ & 0.05 & $(1 / 20)$ \\
\hline & CCL2 & 1.00 & $(20 / 20)$ & 0.90 & $(18 / 20)$ & 0.10 & $(2 / 20)$ & 0.00 & $(0 / 20)$ \\
\hline & CCL7 & 0.95 & $(19 / 20)$ & 0.90 & $(18 / 20)$ & 0.10 & $(2 / 20)$ & 0.05 & $(1 / 20)$ \\
\hline & CXCL10 & 0.75 & $(15 / 20)$ & 0.90 & $(18 / 20)$ & 0.10 & $(2 / 20)$ & 0.25 & $(5 / 20)$ \\
\hline & CXCL11 & 0.75 & $(15 / 20)$ & 0.95 & $(19 / 20)$ & 0.05 & $(1 / 20)$ & 0.25 & $(5 / 20)$ \\
\hline & CXCL5 + CCL2 + CCL7 & 1.00 & $(20 / 20)$ & 0.90 & $(18 / 20)$ & 0.10 & $(2 / 20)$ & 0.00 & $(0 / 20)$ \\
\hline
\end{tabular}


Table 4. Sensitivity and specificity of gene expression of five chemokines in the pulmonary toxicity of nanomaterials.

\begin{tabular}{|c|c|c|c|c|c|c|c|c|c|}
\hline & & \multicolumn{2}{|c|}{ Sensitivity } & \multicolumn{2}{|c|}{ Specificity } & \multicolumn{2}{|c|}{ False Positive } & \multicolumn{2}{|c|}{ False Negative } \\
\hline \multirow{6}{*}{1 month } & CXCL5 & 0.95 & $(19 / 20)$ & 1.00 & $(20 / 20)$ & 0.00 & $(0 / 20)$ & 0.05 & $(1 / 20)$ \\
\hline & CCL2 & 1.00 & $(20 / 20)$ & 0.90 & $(18 / 20)$ & 0.10 & $(2 / 20)$ & 0.00 & $(0 / 20)$ \\
\hline & CCL7 & 1.00 & $(20 / 20)$ & 0.95 & $(19 / 20)$ & 0.05 & $(1 / 20)$ & 0.00 & $(0 / 20)$ \\
\hline & CXCL10 & 0.65 & $(13 / 20)$ & 1.00 & $(20 / 20)$ & 0.00 & $(0 / 20)$ & 0.35 & $(7 / 20)$ \\
\hline & CXCL11 & 0.65 & $(13 / 20)$ & 0.95 & $(19 / 20)$ & 0.05 & $(1 / 20)$ & 0.35 & $(7 / 20)$ \\
\hline & $C X C L 5+C C L 2+C C L 7$ & 1.00 & $(20 / 20)$ & 0.90 & $(18 / 20)$ & 0.10 & $(2 / 20)$ & 0.00 & $(0 / 20)$ \\
\hline \multirow{6}{*}{3 months } & CXCL5 & 1.00 & $(20 / 20)$ & 0.95 & $(19 / 20)$ & 0.05 & $(1 / 20)$ & 0.00 & $(0 / 20)$ \\
\hline & CCL2 & 0.95 & $(19 / 20)$ & 0.80 & $(16 / 20)$ & 0.20 & $(4 / 20)$ & 0.50 & $(1 / 20)$ \\
\hline & CCL7 & 0.95 & $(19 / 20)$ & 0.80 & $(16 / 20)$ & 0.20 & $(4 / 20)$ & 0.50 & $(1 / 20)$ \\
\hline & CXCL10 & 0.75 & $(15 / 20)$ & 0.80 & $(16 / 20)$ & 0.20 & $(4 / 20)$ & 0.25 & $(5 / 20)$ \\
\hline & CXCL11 & 0.90 & $(18 / 20)$ & 0.75 & $(15 / 20)$ & 0.25 & $(5 / 20)$ & 0.10 & $(2 / 20)$ \\
\hline & $C X C L 5+C C L 2+C C L 7$ & 1.00 & $(20 / 20)$ & 0.80 & $(16 / 20)$ & 0.20 & $(4 / 20)$ & 0.00 & $(0 / 20)$ \\
\hline \multirow{6}{*}{6 months } & CXCL5 & 0.95 & $(19 / 20)$ & 0.80 & $(16 / 20)$ & 0.20 & $(4 / 20)$ & 0.05 & $(1 / 20)$ \\
\hline & CCL2 & 0.85 & $(17 / 20)$ & 0.80 & $(16 / 20)$ & 0.20 & $(4 / 20)$ & 0.15 & $(3 / 20)$ \\
\hline & CCL7 & 0.85 & $(17 / 20)$ & 0.85 & $(17 / 20)$ & 0.15 & $(3 / 20)$ & 0.15 & $(3 / 20)$ \\
\hline & CXCL10 & 0.55 & $(11 / 20)$ & 0.80 & $(16 / 20)$ & 0.20 & $(4 / 20)$ & 0.45 & $(9 / 20)$ \\
\hline & CXCL11 & 1.00 & $(20 / 20)$ & 0.70 & $(14 / 20)$ & 0.30 & $(6 / 20)$ & 0.00 & $(0 / 20)$ \\
\hline & $C X C L 5+C C L 2+C C L 7$ & 1.00 & $(20 / 20)$ & 0.30 & $(6 / 20)$ & 0.70 & $(14 / 20)$ & 0.00 & $(0 / 20)$ \\
\hline
\end{tabular}

Sensitivity $=$ (the number of true positives/the number of true positives + the number of false negatives). Specificity $=$ (the number of true negatives/the number of false positives + the number of true negatives). False positive $=$ (the number of false positives/the number of false positives + the number of true negatives). False negatives $=$ (the number of false negatives/the number of true positives + the number of false negatives).

\subsection{CXCL5, CCL2 and CCL7 Immunostaining}

Figure 2 shows CXCL5, CCL2, and CCL7 immunostaining in the NiO-high dose group and the negative control group at one month after intratracheal instillation. The CXCL5 immunostaining positive cells were mainly observed at the gathering sites of inflammatory cells, mainly macrophages, at one month in the high dose of $\mathrm{NiO}$ exposure group. Similar to CXCL5, the positive cells of CCL2 and CCL7 immunostaining were observed in aggregations of inflammatory cells centered on macrophages.

HE

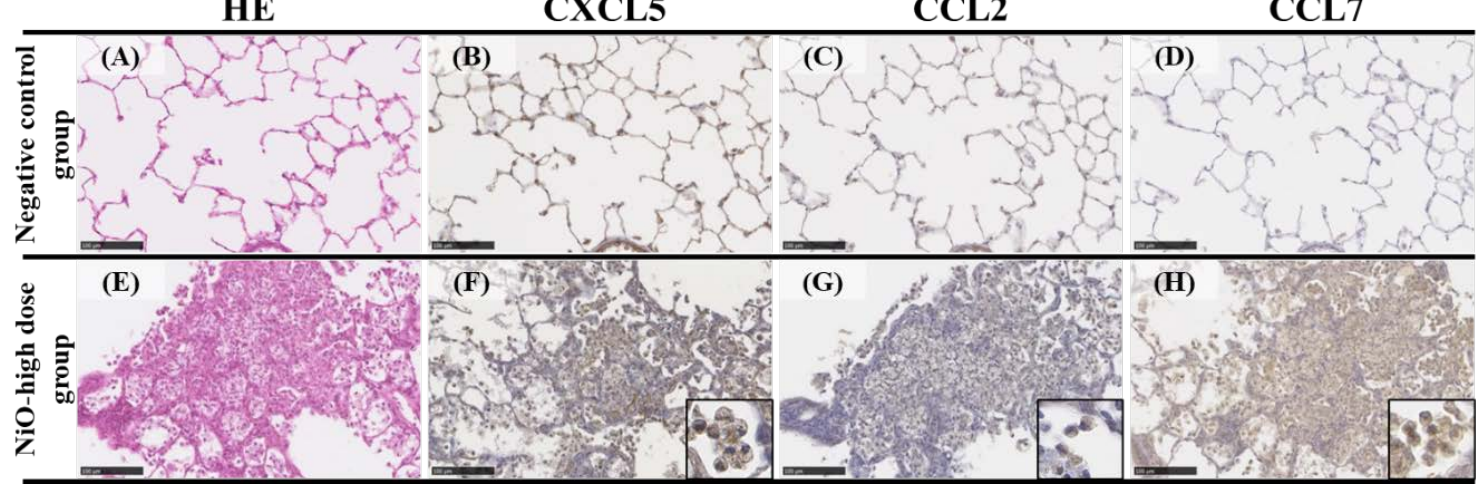

Figure 2. Representative images of CXCL5, CCL2, and CCL7 immunostaining in lung tissue exposed to NiO. (A-D): the negative control lungs; (A) H\&E staining; (B) CXCL5 immunostaining; (C) CCL2 immunostaining; (D)CCL7 immunostaining. (E-H): the NiO-high dose exposed lungs; (E) H\&E staining; (F) CXCL5 immunostaining; (G) CCL2 immunostaining; (H) CCL7 immunostaining. All of the examples illustrate findings at 1 month after intratracheal instillation: Positive cells of CXCL5, CCL2, and CCL7 immunostaining on NiO-exposed lungs were mainly macrophages. (internal scale bar $=100 \mu \mathrm{m}$ for all).

\subsection{Pathological Features in the Rat Lungs}

Figure 3 shows the inflammatory cell infiltration scores of the pathological features in the rat lungs. There was sustained inflammation in the rat lungs that were exposed to $\mathrm{NiO}$ and $\mathrm{CeO}_{2}$, while only transient inflammation was observed in rat lungs exposed to $\mathrm{TiO}_{2}$ and $\mathrm{ZnO}$. In Figure 4, 
pulmonary inflammation appears mainly in the macrophages and neutrophils in the rat lungs that were exposed to $\mathrm{NiO}$, and in the macrophages in the rat lungs exposed to $\mathrm{CeO}_{2}$, respectively. We previously reported that inflammatory cells influx in the bronchoalvelar lavage fluid was persistent in the $\mathrm{NiO}$ and $\mathrm{CeO}_{2}$ groups, whereas it was transient in the $\mathrm{TiO}_{2}$ and $\mathrm{ZnO}$ groups and these findings were similar to the pathological features of each group [19-21]. Figure 5 shows the relationship between the inflammatory cell score and the gene expression of CXCL5, CCL2, CCL7, CXCL10, and CXCL11 in the lung exposed to the nanomaterials. The expression levels of CXCL5, CCL2, and CCL7 at one week and one month correlated moderately or strongly with the degree of inflammatory cell infiltration in the lung tissue.

\section{Inflammatory cell infiltration score $\mathrm{NiO}$}

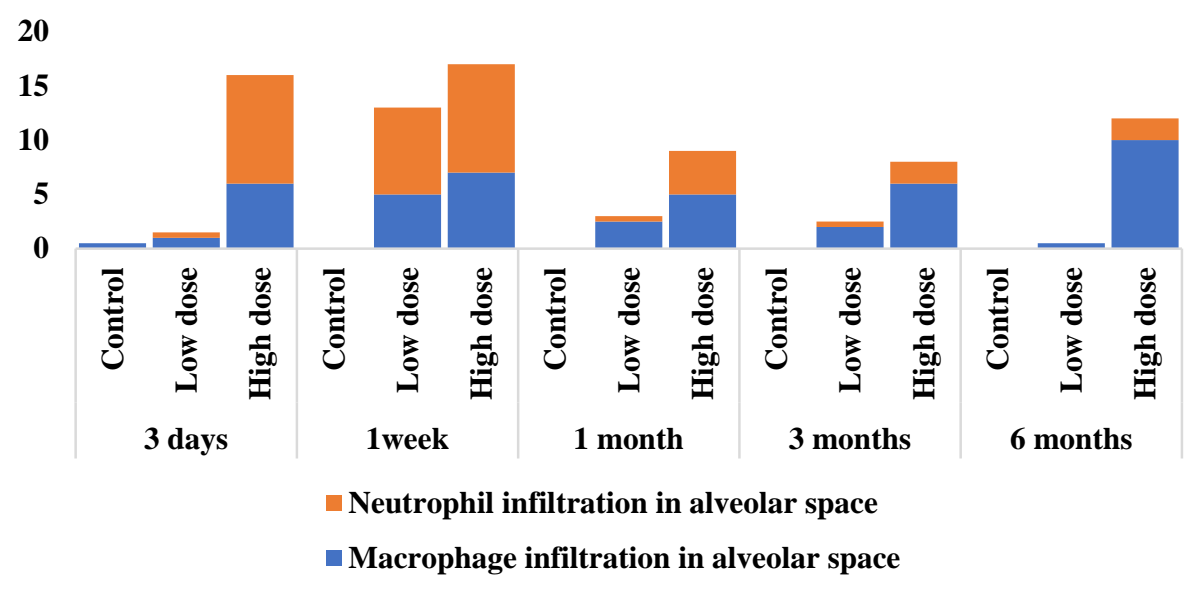

(A)

\section{Inflammatory cell infiltration score $\mathrm{CeO}_{2}$}

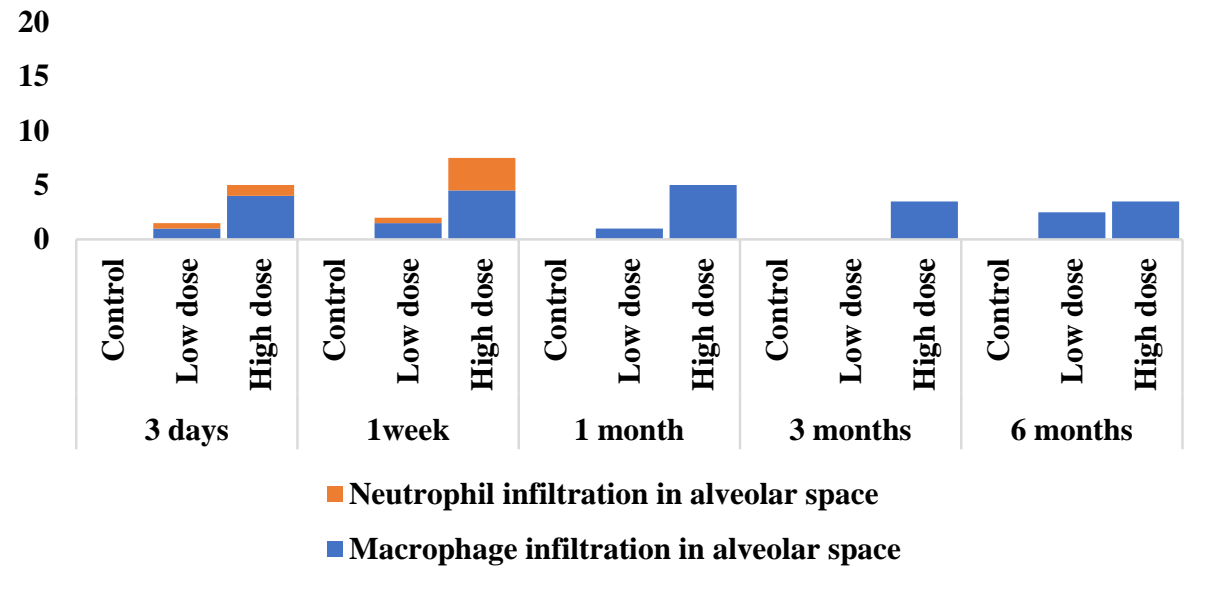

(B)

Figure 3. Cont. 


\section{Inflammatory cell infiltaration score \\ $\mathrm{TiO}_{2}$}

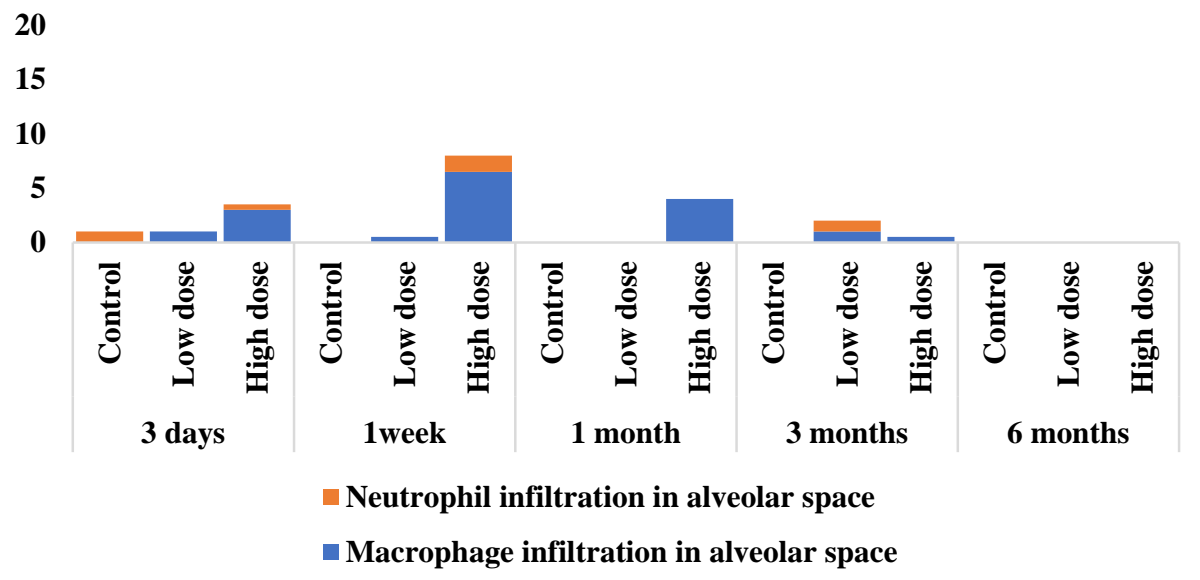

(C)

\section{Inflammatory cell infiltration score \\ ZnO}

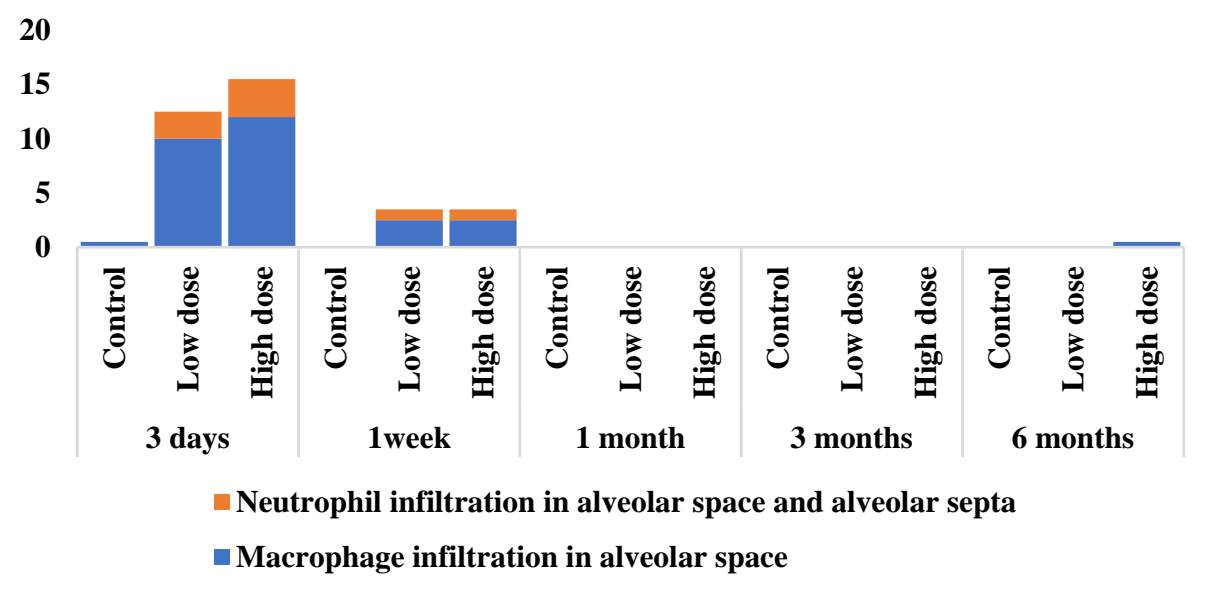

(D)

Figure 3. Score of inflammatory cell infiltration in the lung exposed to nanomaterials. (A) the $\mathrm{NiO}$-exposed group; (B) the $\mathrm{CeO}_{2}$-exposed group; (C) the $\mathrm{TiO}_{2}$-exposed group; (D) the $\mathrm{ZnO}$ exposed-group. The severity of lung histological changes in the negative control and nanoparticle-exposed rats was scored as none (0), minimal (0.5), mild (1), moderate (2), or severe (3). Exposure to $\mathrm{NiO}$ and $\mathrm{CeO}_{2}$ resulted in persistent infiltration of inflammatory cells throughout the observation period, but $\mathrm{TiO}_{2}$ and $\mathrm{ZnO}$ only showed a transient infiltration. The score is calculated with a following equation. $\Sigma$ (grade $\times$ number of animals with grade). The low dose groups and the high dose groups were exposed $0.2 \mathrm{mg} 1.0 \mathrm{mg}$, respectively. 

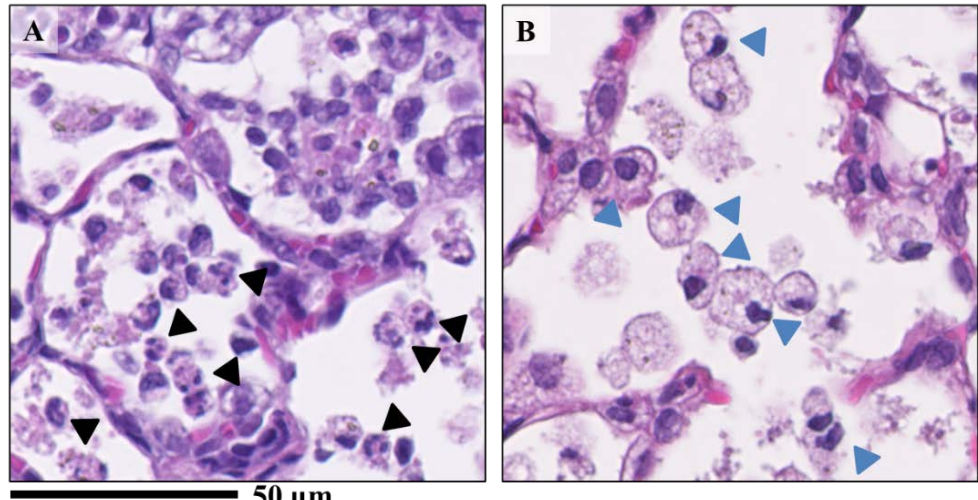

Figure 4. Lung samples sectioned with $\mathrm{H} \& \mathrm{E}$ staining exposed to nanomaterials intratracheally. (A) the NiO-high dose exposed group; (B) the $\mathrm{CeO}_{2}$-high dose group. There were differences of infiltrating inflammatory cells between nanomaterials. While mainly neutrophils and macrophages were found in the alveoli in the NiO-high dose group (A), macrophage-based inflammatory cell infiltration was observed in the $\mathrm{CeO}_{2}$-high dose group (B). Black arrow heads indicate neutrophils and blue arrow heads indicates macrophages.

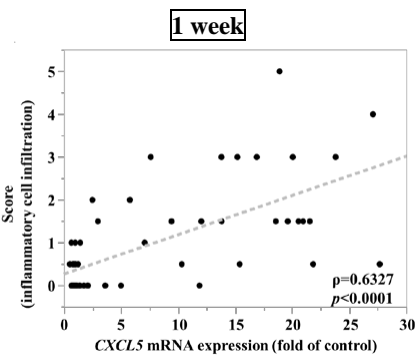

(A)

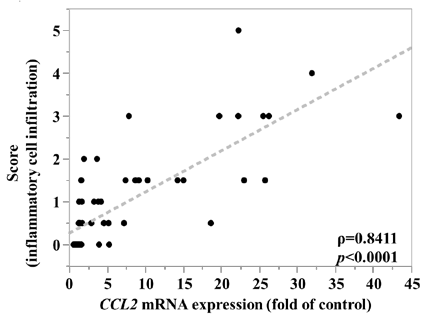

(C)

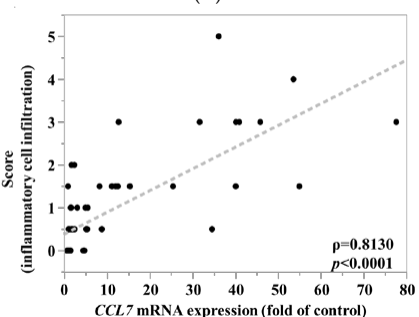

(E)

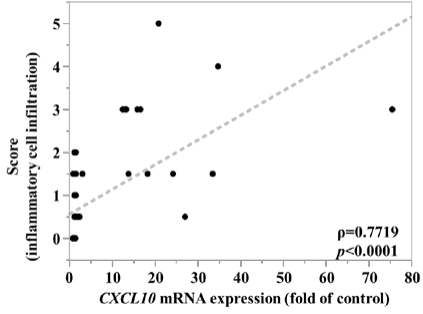

(G)

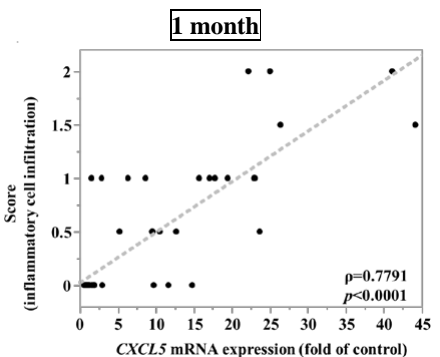

(B)

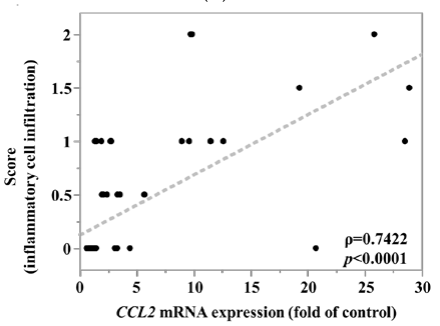

(D)

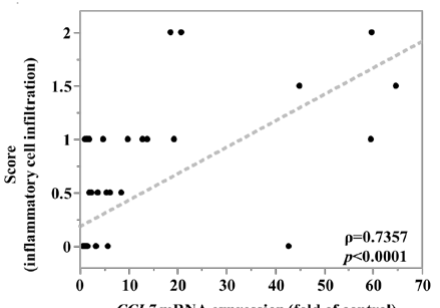

(F)

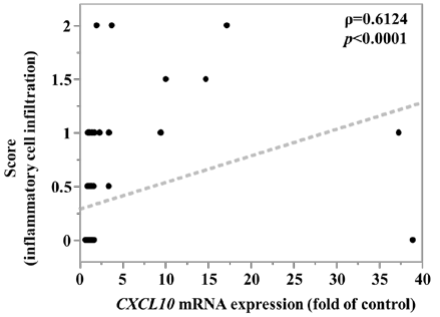

(H)

Figure 5. Cont. 


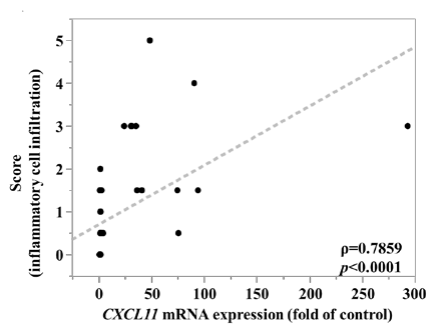

(I)

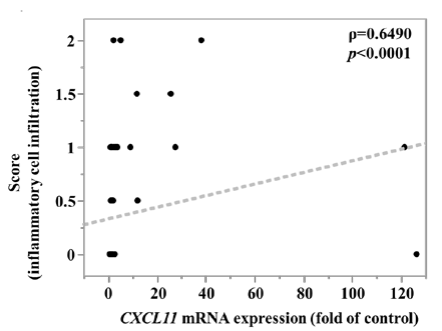

(J)

Figure 5. Relationship between inflammatory cell infiltration and gene expression of each 5 chemokines in exposed lung. (A) CXCL5 mRNA expression, (C) CCL2 mRNA expression, (E) CCL7 mRNA expression, (G) CXCL10 mRNA expression, (I) CXCL11 mRNA expression at 1 week after the instillation versus score of inflammatory cell infiltration and (B) CXCL5 mRNA expression, (D) CCL2 mRNA expression, (F) CCL7 mRNA expression, (H) CXCL10 mRNA expression, (J) CXCL11 mRNA expression at 1 month after the instillation versus score of inflammatory cell infiltration. There was relatively good correlation between inflammatory cell infiltration in lung tissues and CXCL5, CCL2, and CCL7 at one week and one month after intratracheal instillation.

\section{Discussion}

According to the microarray analysis in our experiments, the inflammation-related genes that showed an upregulation in the lungs of rats injected intratracheally with $\mathrm{NiO}$ nanoparticles were CXCL5, CCL2, CCL7, CXCL10, and CXCL11, all of which are chemokine genes. All of these chemokines are involved in inflammatory responses through the migration, accumulation, and activation of inflammatory cells, such as neutrophils and macrophages [33-36].

CXCL5 is a CXC chemokine with a glutamate-leucine-arginine (ELR) motif (ELR + chemokine) and it has potent chemotactic and activating functions of neutrophils in the lung [37]. In our experiments, the gene expression of CXCL5 was persistently increased by $\mathrm{NiO}$ and $\mathrm{CeO}_{2}$, which have high pulmonary toxicity, and not, or only transiently, increased by $\mathrm{TiO}_{2}$ and $\mathrm{ZnO}$, which have low pulmonary toxicity (Figure 1). In other studies, the expression of CXCL5 by respirable chemicals was enhanced in the lungs of rodents exposed to single-wall carbon nanotubes and inflammogenetic stainless-steel welding fumes [38,39]. For lung lesion other than pulmonary inflammation, exposure to cigarette smoke, which leads to lung cancer and COPD, also induced CXCL5 expression in the lung [40]. Alternatively, no up-regulation of CXCL5 was reported in rat lungs that were exposed to C60 fullerenes with low toxicity [41].

The chemokines CCL2 and CCL7 are known as chemotactic agents for monocytes and they have been found to play a key role in mediating lung inflammation. It is also known that CCL2 and CCL7 are both CC chemokines, are closely related to each other, have a common receptor (CCR2), and elicit similar responses, such as those that are involved in the migration of macrophages, lymphocytes, and neutrophils [42]. Similar to CXCL5 in our experiment, exposure to $\mathrm{NiO}$ and $\mathrm{CeO}_{2}$ showed a continuous, increasing trend of the expression of CCL2 and CCL7, but exposure to $\mathrm{TiO}_{2}$ and $\mathrm{ZnO}$ did so only transiently (Figure 1). Langley et al. found that CCL2 and CCL7 were persistently upregulated in rat lungs that were exposed to inhaled crystalline silica, a dust with high toxicity [43]. Fujita et al. also reported that CCL2 and CCL7 were upregulated in the lungs of rats injected intratracheally with inflammogenetic single-wall carbon nanotube (SWCNT) $[38,44]$. Abdelgied et al. found that CCL2 expression was increased in rat lungs following intratracheal instillation of potassium octatitanate fibers (POT fibers), which are suggested to have carcinogenic potential [45]. On the other hand, it has also been reported that $C C L 2$ and $C C L 7$ expression was transient in rat lungs following the intratracheal instillation of $\mathrm{C} 60$ fullerenes with low toxicity [41].

The expression of CXCL5, CCL2, and CCL7 had a certain level of correlation with the lung inflammation score in our experiment, and these findings suggested that these gene expressions were involved in lung inflammation as the main pathological lesion from exposure to nanomaterials. Immunostaining results revealed that CXCL5, CCL2, and CCL7 mainly stained macrophages in the 
infiltration of inflammatory cells in the alveolar space, although only lung tissues that were exposed to $\mathrm{NiO}$ were examined. This suggests that these chemokines in the alveolar space also contributed to the formation of pulmonary inflammation.

CXCL10 and CXCL11 are ELR- CXC chemokines that have CXCR3 as a common receptor [46]. No difference in the expression level between nanomaterials of high and low pulmonary toxicity was observed in our experiment. Fundamentally, CXCL10 and CXCL11, which are Th1 network-related cytokines, seem to have little relation to this pathological condition in which the inflammatory cells are mainly macrophages and neutrophils. The $\mathrm{T}$ cells were rarely involved in the lesions in the present experiment, which is the reason why these genes expressions are not reflected in the ranking.

There was a considerable relationship between the toxicity ranking of the nanomaterials and the expression of CXCL5, CCL2 and CCL7, which have AUC with high values. Under the condition of high AUC, low doses of highly toxic substances produced more gene expression than high doses of less toxic substances. The dosage settings in this experiment, $0.8 \mathrm{mg} / \mathrm{kg} \mathrm{BW}$ and $4 \mathrm{mg} / \mathrm{kg} \mathrm{BW}$, were necessary for considering the validity of the expression level of the three genes. We considered that the low and high dosages were approximately the minimum and maximum doses that are necessary for evaluating the pulmonary toxicity of the metal oxide nanoparticles in our experiment. The low dose is approximately the minimum dose at which nanomaterials with high toxicity induced pulmonary inflammation. We previously injected $\mathrm{NiO}$ at $0.8 \mathrm{mg} / \mathrm{kg} \mathrm{BW}$ in rats of a different species than those in the present experiment, and there was similar mild neutrophil inflammation [10]. The dose of $4 \mathrm{mg} / \mathrm{kg}$ BW was considered to be the maximum dose that did not cause overload in intratracheal instillation studies of nanoparticles. We previously reported that doses in excess of $4 \mathrm{mg} / \mathrm{kg}$ induced pulmonary surplus inflammation and the delay of the biological half time of nanoparticles [47]. Morrow PE et al. and Bellmann B et al. reported in toner studies, as well, which a delayed clearance of alveolar macrophages occurred between $1 \mathrm{mg} / \mathrm{rat}(4 \mathrm{mg} / \mathrm{kg}$ BW in our experiment is equivalent to $1 \mathrm{mg} / \mathrm{rat}$ ) and $3 \mathrm{mg} / \mathrm{rat}$ of lung deposition [48,49], indicating that the threshold of overload is between 1 and $3 \mathrm{mg} / \mathrm{rat}$. It was speculated from these data that exposure to doses above $1 \mathrm{mg} / \mathrm{rat} \mathrm{might}$ induce pulmonary toxicity by the chemicals themselves as well as toxicity from the excessive dose. These doses, $0.8 \mathrm{mg} / \mathrm{kg} \mathrm{BW}$ and $4 \mathrm{mg} / \mathrm{kg} \mathrm{BW}$, as the burden on the lungs of nanomaterials after intratracheal instillation, may correspond to approximately 0.36 and 1.8 years of the inhalation period at a concentration of $3 \mathrm{mg} / \mathrm{m}^{3}$, respectively, as the maximum concentration for humans of inhalable dust without crystalline silica (working time $8 \mathrm{~h} /$ day, five days/week) defined by the American Conference of Governmental Industrial Hygienists (ACGIH).

As for the examination of the observation times, there were high AUCs between the pulmonary toxicity of the nanomaterials and the gene expression of the three chemokines at one month and one week following intratracheal instillation. In the acute phases, for example, at around three days after intratracheal instillation, there may have been a bolus effect in which even low-toxic substances induced pulmonary inflammation. Yoshiura et al. reported that even $\mathrm{TiO}_{2}(\mathrm{P90})$, which did not cause pulmonary tumors in two years observation time following intratracheal instillation, induced transient inflammation at three days in the same intratracheal instillation study [27]. ZnO is known to be a soluble metal oxide that causes inflammation, and in our experiment, $\mathrm{ZnO}$ nanoparticles, among the four nanomaterials studied, induced severe pulmonary inflammation at three days following intratracheal instillation. At one month, the pulmonary inflammation by the bolus effect had disappeared, and the gene may have been expressed due to the toxicity of the original nanomaterial. Although some inflammation remained in the low toxic substance exposure group at one week (Figure 3), there was a difference in the degree of gene expression between the high and low toxic nanomaterials. It is considered that the decrease in the expression of chemokines may have proceeded from the cessation of inflammation at one week following intratracheal instillation. Oh JH et al. reported that the expression of CXCL5, CCL2, and CCL7 in rat lungs from inhaled stainless-steel 
welding fumes returned to negative control levels earlier than inflammation as pathological changes in the lung [39].

Regarding the up-regulation of these three genes, there seems to be no common transcription factor, but it may be involved in the activation of TGF- $\beta$-activated kinase 1 (TAK1), which activates NF- $\mathrm{kB}$, JNK, and $\mathrm{p} 38 \mathrm{MARK}$, which are known transcription factors and regulatory factors for many chemokines. Thiesfes et al. reported that the gene expression of CXCL5, CCL2, and CCL7 in the same experimental condition was stimulated by TNF through TAK1 activity in NIH3T3 cells [50]. Li et al. also reported that TAK1 inhibition suppressed inflammation and fibrosis in a pneumoconiosis animal model [51].

As described above, because the gene expression of the three chemokines is stable and reflects the difference in pulmonary toxicity of nanomaterials between different doses $(0.8$ and $4 \mathrm{mg} / \mathrm{kg} \mathrm{BW})$, and different observation periods (one week and one month as observation times), these three chemokine genes, $C X C L 5, C C L 2$, and $C C L 7$, are considered to be useful as biomarkers for the ranking of the pulmonary toxicity of nanomaterials.

When the pulmonary toxicity of the nanomaterials was screened in this intratracheal instillation model, it is important that there were no false negatives. If the screening criteria for pulmonary toxicity of nanomaterials is that any of the three gene expressions exceed the cut-off value, false negatives as a screening test would have been minimum in this experiment (Table 4). Therefore, we think that the combination of these three genes, CXCL5, CCL2, and CCL7, is useful for screening the pulmonary toxicity of nanomaterials.

\section{Conclusions}

We analyzed the mRNA expression of chemokines in rat lungs following intratracheal instillation of four different nanomaterials in order to find useful predictive markers of the pulmonary toxicity of nanomaterials. Our results suggest that three chemokine genes, especially CXCL5, followed by CCL2 and $C C L 7$, can be useful as biomarkers for the ranking of the pulmonary toxicity of nanomaterials.

Author Contributions: Authors C.N., H.I., K.Y. (Kazuhiro Yatera) and Y.M. are responsible for the study design and writing of the manuscript. Authors C.N., H.I., T.T., J.-i.T. and K.Y. (Kei Yamasaki) are responsible for data and analysis. Authors C.N., H.I., T.T., K.-Y.W. and Y.M. performed the experiments. All authors have read and agreed to the published version of the manuscript.

Funding: The study was funded by the "Development of Innovative Methodology for Safety Assessment of Industrial Nanomaterials" by the Ministry of Economy, Trade and Industry (METI) of Japan.

Acknowledgments: The authors would like to thank M. Shijo, R. Takai, M. Tashiro and Y. Yoshiura for technical support with the experiments. This research was supported by the "Development of Innovative Methodology for Safety Assessment of METI of Japan.

Conflicts of Interest: The authors declare no conflict of interest.

\section{Appendix A}

Table A1. (A) Confusion matrix. (B) Example of confusion matrix.

\begin{tabular}{|c|c|c|c|}
\hline \multicolumn{4}{|c|}{ (A) Confusion matrix } \\
\hline & & \multicolumn{2}{|c|}{ Pulmonary Toxicity } \\
\hline & & High & Low \\
\hline \multirow[t]{2}{*}{$\begin{array}{c}\text { Gene } \\
\text { expression } \\
\text { level } \\
\text { (fold of control) }\end{array}$} & $\begin{array}{l}\geqq \text { Cut off } \\
\text { value } \\
<\text { Cut off } \\
\text { value }\end{array}$ & $\begin{array}{c}\mathrm{a} \\
\text { (True positives) } \\
\mathrm{c} \\
\text { (False negatives) }\end{array}$ & $\begin{array}{c}\mathrm{b} \\
\text { (False positives) } \\
\mathrm{d} \\
\text { (True negatives) }\end{array}$ \\
\hline & & $a+c$ & $b+d$ \\
\hline
\end{tabular}


Table A1. (A) Confusion matrix. (B) Example of confusion matrix.

\begin{tabular}{|c|c|c|c|}
\hline \multicolumn{4}{|c|}{ 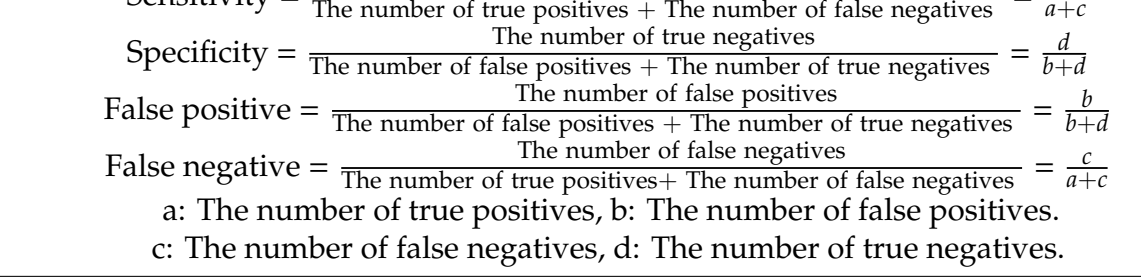 } \\
\hline \multicolumn{4}{|c|}{ (B) Example of confusion matrix. } \\
\hline \multicolumn{2}{|r|}{$\begin{array}{l}\text { CXCL5 } \\
\text { at } 1 \text { week }\end{array}$} & $\begin{array}{r}\quad P \\
\text { High }\end{array}$ & y \\
\hline \multirow[t]{2}{*}{$\begin{array}{c}\text { Gene } \\
\text { expression } \\
\text { level } \\
\text { (fold of control) }\end{array}$} & $\begin{array}{l}\geqq \text { Cut off } \\
\text { value } \\
<\text { Cut off } \\
\text { value }\end{array}$ & 19 & 20 \\
\hline & & 20 & 20 \\
\hline & $\begin{array}{l}\text { mple, in CX } \\
\text { ty }=\frac{19}{19+1}= \\
e=\frac{0}{0+20}=\end{array}$ & $\begin{array}{l}\text { after in } \\
\text { ty }=\frac{}{0} \\
\text { ative }=\end{array}$ & \\
\hline
\end{tabular}

Table A2. $p$ values of gene expression of 5 chemokines in lung exposed to nanomaterials.

\begin{tabular}{|c|c|c|c|c|c|}
\hline CXCL5 & \multirow{2}{*}{3 Days } & \multirow{2}{*}{1 Week } & \multirow{2}{*}{1 Month } & \multirow{2}{*}{3 Months } & \multirow{2}{*}{6 Months } \\
\hline Low Dose Group & & & & & \\
\hline $\mathrm{NiO}$ & $0.0037^{* *}$ & $0.0008^{* *}$ & $0.0134^{*}$ & $0.0056^{* *}$ & 0.1862 \\
\hline $\mathrm{CeO}_{2}$ & $0.0002 * *$ & $<0.0001 * *$ & $0.0003^{* *}$ & $0.0302 * *$ & 0.3518 \\
\hline $\mathrm{TiO}_{2}$ & 0.4254 & 0.4474 & 0.9 & 0.2214 & 0.8551 \\
\hline $\mathrm{ZnO}$ & 0.1483 & 0.6346 & 0.7478 & 0.3446 & 0.1679 \\
\hline CCL2 & \multirow{2}{*}{3 Days } & \multirow{2}{*}{1 Week } & \multirow{2}{*}{1 Month } & \multirow{2}{*}{3 Months } & \multirow{2}{*}{6 Months } \\
\hline Low Dose Group & & & & & \\
\hline $\mathrm{NiO}$ & 0.5879 & $0.0017^{* *}$ & 0.8141 & 0.8456 & 0.4627 \\
\hline $\mathrm{CeO}_{2}$ & 0.0170 * & 0.1357 & 0.2553 & 0.5301 & 0.9883 \\
\hline $\mathrm{TiO}_{2}$ & 0.9217 & 0.9928 & 0.737 & 0.1995 & 0.5812 \\
\hline $\mathrm{ZnO}$ & $0.0011^{* *}$ & 0.926 & 0.6449 & 0.358 & 0.2674 \\
\hline CCL7 & \multirow{2}{*}{3 Days } & \multirow{2}{*}{1 Week } & \multirow{2}{*}{1 Month } & \multirow{2}{*}{3 Months } & \multirow{2}{*}{6 Months } \\
\hline Low Dose Group & & & & & \\
\hline $\mathrm{NiO}$ & 0.8425 & $0.0018^{* *}$ & 0.8701 & 0.9175 & 0.608 \\
\hline $\mathrm{CeO}_{2}$ & 0.1495 & 0.3895 & 0.4254 & 0.8892 & 1 \\
\hline $\mathrm{TiO}_{2}$ & 0.9424 & 0.9997 & 0.9087 & 0.2562 & 0.6004 \\
\hline $\mathrm{ZnO}$ & $0.0019^{* *}$ & 0.5976 & 0.6198 & 0.3636 & 0.1821 \\
\hline CXCL10 & \multirow{2}{*}{3 Days } & \multirow{2}{*}{1 Week } & \multirow{2}{*}{1 Month } & \multirow{2}{*}{3 Months } & \multirow{2}{*}{6 Months } \\
\hline Low Dose Group & & & & & \\
\hline $\mathrm{NiO}$ & 0.9877 & $0.0053^{* *}$ & 0.9959 & 0.8678 & 0.3692 \\
\hline $\mathrm{CeO}_{2}$ & 0.161 & 0.4941 & 0.5374 & 0.9784 & 0.3855 \\
\hline $\mathrm{TiO}_{2}$ & 0.9956 & 0.9929 & 0.7097 & 0.212 & 0.592 \\
\hline $\mathrm{ZnO}$ & $<0.0001^{* *}$ & $0.0002^{* *}$ & 0.4146 & 0.3867 & 0.3168 \\
\hline
\end{tabular}


Table A2. $p$ values of gene expression of 5 chemokines in lung exposed to nanomaterials.

\begin{tabular}{|c|c|c|c|c|c|}
\hline CXCL11 & \multirow{2}{*}{3 Days } & \multirow{2}{*}{1 Week } & \multirow{2}{*}{1 Month } & \multirow{2}{*}{3 Months } & \multirow{2}{*}{6 Months } \\
\hline Low Dose Group & & & & & \\
\hline $\mathrm{NiO}$ & 0.9995 & $0.0289 *$ & 0.9985 & 0.8235 & 0.4274 \\
\hline $\mathrm{CeO}_{2}$ & 0.2719 & 0.5391 & 0.5132 & 0.9954 & 0.6872 \\
\hline $\mathrm{TiO}_{2}$ & 0.9996 & 0.9982 & 0.7218 & 0.2127 & 0.2207 \\
\hline $\mathrm{ZnO}$ & $<0.0001^{* *}$ & $0.0038^{* *}$ & 0.7349 & 0.3887 & 0.1187 \\
\hline CXCL5 & \multirow{2}{*}{3 Days } & \multirow{2}{*}{1 Week } & \multirow{2}{*}{1 Month } & \multirow{2}{*}{3 Months } & \multirow{2}{*}{6 Months } \\
\hline High dose group & & & & & \\
\hline $\mathrm{NiO}$ & $0.0063 * *$ & $0.0003^{* *}$ & $<0.0001 * *$ & $<0.0001^{* *}$ & $<0.0001^{* *}$ \\
\hline $\mathrm{CeO}_{2}$ & $0.0004^{* *}$ & $<0.0001^{* *}$ & $<0.0001^{* *}$ & $<0.0301 *$ & $0.0020 * *$ \\
\hline $\mathrm{TiO}_{2}$ & $<0.0001^{* *}$ & $0.0053^{* *}$ & 0.0133 * & 0.7013 & 0.4984 \\
\hline $\mathrm{ZnO}$ & 0.1626 & 0.6737 & 0.6125 & 0.4968 & $0.0405^{*}$ \\
\hline CCL2 & \multirow{2}{*}{3 Days } & \multirow{2}{*}{1 Week } & \multirow{2}{*}{1 Month } & \multirow{2}{*}{3 Months } & \multirow{2}{*}{6 Months } \\
\hline High Dose Group & & & & & \\
\hline $\mathrm{NiO}$ & $<0.0001$ ** & $0.0022 * *$ & $0.0003 * *$ & $0.0025^{* *}$ & $<0.0001^{* *}$ \\
\hline $\mathrm{CeO}_{2}$ & $<0.0001^{* *}$ & $0.0156^{*}$ & 0.0130 * & $0.0004^{* *}$ & 0.0177 * \\
\hline $\mathrm{TiO}_{2}$ & $<0.0001^{* *}$ & 0.1091 & $0.0267 *$ & 0.8836 & 0.9128 \\
\hline $\mathrm{ZnO}$ & $0.0020 * *$ & 0.6238 & 0.9559 & 0.4076 & 0.3763 \\
\hline CCL7 & \multirow{2}{*}{3 Days } & \multirow{2}{*}{1 Week } & \multirow{2}{*}{1 Month } & \multirow{2}{*}{3 Months } & \multirow{2}{*}{6 Months } \\
\hline High Dose Group & & & & & \\
\hline $\mathrm{NiO}$ & $<0.0001 * *$ & $0.0031^{* *}$ & $0.0004^{* *}$ & $0.0064^{* *}$ & $<0.0001^{* *}$ \\
\hline $\mathrm{CeO}_{2}$ & $<0.0001^{* *}$ & 0.0889 & 0.0782 & $0.0141 *$ & $0.0327^{*}$ \\
\hline $\mathrm{TiO}_{2}$ & $0.0008^{* *}$ & 0.2082 & 0.0651 & 0.9479 & 0.8681 \\
\hline $\mathrm{ZnO}$ & 0.0110 * & 0.5797 & 0.9974 & 0.4146 & 0.8918 \\
\hline CXCL10 & \multirow{2}{*}{3 Days } & \multirow{2}{*}{1 Week } & \multirow{2}{*}{1 Month } & \multirow{2}{*}{3 Months } & \multirow{2}{*}{6 Months } \\
\hline High Dose Group & & & & & \\
\hline $\mathrm{NiO}$ & $0.0004^{* *}$ & 0.2108 & $0.0081^{* *}$ & 0.1018 & 0.9967 \\
\hline $\mathrm{CeO}_{2}$ & 0.3798 & 0.5606 & 0.4095 & 0.1205 & 0.5615 \\
\hline $\mathrm{TiO}_{2}$ & 0.0613 & 0.2908 & 0.9398 & 0.9278 & 0.3888 \\
\hline $\mathrm{ZnO}$ & $0.0011^{* *}$ & 0.0655 & 0.54 & 0.4204 & 0.659 \\
\hline CXCL11 & \multirow{2}{*}{3 Days } & \multirow{2}{*}{1 Week } & \multirow{2}{*}{1 Month } & 3 Monthe & 6Monthe \\
\hline High Dose Group & & & & ร & ด 1จ \\
\hline $\mathrm{NiO}$ & $0.0014^{* *}$ & 0.6045 & $0.0277 *$ & 0.097 & 0.2332 \\
\hline $\mathrm{CeO}_{2}$ & 0.2058 & 0.5708 & 0.4182 & 0.1515 & 0.2836 \\
\hline $\mathrm{TiO}_{2}$ & 0.1343 & 0.3348 & 0.7182 & 0.9359 & 0.2013 \\
\hline $\mathrm{ZnO}$ & $<0.0001^{* *}$ & 0.0672 & 0.4405 & 0.3996 & 0.4958 \\
\hline
\end{tabular}

Asterisks indicate significant differences compared with each control (Dunnett' test) $\left.{ }^{*} p<0.05,{ }^{* *} p<0.01\right)$.

\section{References}

1. Borm, P.J.A.; Robbins, D.; Haubold, S.; Kuhlbusch, T.; Fissan, H.; Donaldson, K.; Schins, R.; Stone, V.; Kreyling, W.; Lademann, J.; et al. The potential risks of nanomaterials: A review carried out for ECETOC. Part. Fibre Toxicol. 2006, 3, 11. [CrossRef]

2. ISO/TS. ISO/TS 27687:2008(en). Nanotechnologies. Terminology and Definitions for Nano-Objects-Nanoparticle, Nanofibre and Nanoplate. Available online: https://www.iso.org/obp/ui/\#iso:std:iso:ts:27687:ed-1:v2:en (accessed on 12 May 2020).

3. Suzui, M.; Futakuchi, M.; Fukamachi, K.; Numano, T.; Abdelgied, M.; Takahashi, S.; Ohnishi, M.; Omori, T.; Tsuruoka, S.; Hirose, A.; et al. Multiwalled carbon nanotubes intratracheally instilled into the rat lung induce development of pleural malignant mesothelioma and lung tumors. Cancer Sci. 2016, 107, 924-935. [CrossRef] [PubMed] 
4. Numano, T.; Higuchi, H.; Alexander, D.B.; Alexander, W.T.; Abdelgied, M.; El-Gazzar, A.M.; Saleh, D.; Takase, H.; Hirose, A.; Naiki-Ito, A.; et al. MWCNT-7 administered to the lung by intratracheal instillation induces development of pleural mesothelioma in F344 rats. Cancer Sci. 2019, 110, 2485-2492. [CrossRef]

5. Kasai, T.; Umeda, Y.; Ohnishi, M.; Mine, T.; Kondo, H.; Takeuchi, T.; Matsumoto, M.; Fukushima, S. Lung carcinogenicity of inhaled multi-walled carbon nanotube in rats. Part. Fibre Toxicol. 2016, 13, 53. [CrossRef]

6. Borm, P.J.A.; Driscoll, K. Particles, inflammation and respiratory tract carcinogenesis. Toxicol. Lett. 1996, 88, 109-113.

7. Shacter, E.; Weitzman, A.S. Chronic Inflammation and Cancer. Oncology 2002, 16, 217-226.

8. Bellmann, B.; Muhle, H.; Creutzenberg, O.; Ernst, H.; Müller, M.; Bernstein, D.M.; Sintes, J.M.R. Calibration study on subchronic inhalation toxicity of man-made vitreous fibers in rats. Inhal. Toxicol. 2003, 15, 1147-1177. [CrossRef]

9. Kim, H.; Morimoto, Y.; Ogami, A.; Nagatomo, H.; Hirohashi, M.; Oyabu, T.; Kawanami, Y.; Kuroda, E.; Higashi, T.; Tanaka, I. Differential expression of EC-SOD, Mn-SOD and CuZn-SOD in rat lung exposed to crystalline silica. J. Occup. Health 2007, 49, 242-248. [CrossRef] [PubMed]

10. Nishi, K.; Morimoto, Y.; Ogami, A.; Murakami, M.; Myojo, T.; Oyabu, T.; Kadoya, C.; Yamamoto, M.; Todoroki, M.; Hirohashi, M.; et al. Expression of cytokine-induced neutrophil chemoattractant in rat lungs by intratracheal instillation of nickel oxide nanoparticles. Inhal. Toxicol. 2009, 21, 1030-1039. [CrossRef]

11. Pott, F.; Ziem, U.; Reiffer, F.J.; Huth, F.; Ernst, H.; Mohr, U. Carcinogenicity studies on fibres, metal compounds, and some other dusts in rats. Exp. Pathol. 1987, 32, 129-152. [CrossRef]

12. Muhle, H.; Bellmann, B.; Creutzenberg, O.; Dasenbrock, C.; Ernst, H.; Kilpper, R.; MacKenzie, J.; Morrow, P.; Mohr, U.; Takenaka, S.; et al. Pulmonary response to toner upon chronic inhalation exposure in rats. Fundam. Appl. Toxicol. 1991, 17, 280-299. [CrossRef]

13. Senoh, H.; Kano, H.; Suzuki, M.; Fukushima, S.; Oshima, Y.; Kobayashi, T.; Morimoto, Y.; Izumi, H.; Ota, Y.; Takehara, H.; et al. Inter-laboratory comparison of pulmonary lesions induced by intratracheal instillation of $\mathrm{NiO}$ nanoparticle in rats: Histopathological examination results. J. Occup. Health 2020, 62, 1-5. [CrossRef]

14. Pauluhn, J. Subchronic 13-week inhalation exposure of rats to multiwalled carbon nanotubes: Toxic effects are determined by density of agglomerate structures, not fibrillar structures. Toxicol. Sci. 2009, 113, 226-242. [CrossRef] [PubMed]

15. Delorme, M.P.; Muro, Y.; Arai, T.; Banas, D.A.; Frame, S.R.; Reed, K.L.; Warheit, D.B. Ninety-day inhalation toxicity study with a vapor grown carbon nanofiber in rats. Toxicol. Sci. 2012, 128, 449-460. [CrossRef]

16. Aiso, S.; Yamazaki, K.; Umeda, Y.; Asakura, M.; Kasai, T.; Takaya, M.; Toya, T.; Koda, S.; Nagano, K.; Arito, H.; et al. Pulmonary toxicity of intratracheally instilled multiwall carbon nanotubes in male fischer 344 rats. Ind. Health 2010, 48, 783-795. [CrossRef]

17. Morimoto, Y.; Hirohashi, M.; Ogami, A.; Oyabu, T.; Myojo, T.; Todoroki, M.; Yamamoto, M.; Hashiba, M.; Mizuguchi, Y.; Lee, B.W.; et al. Pulmonary toxicity of well-dispersed multi-wall carbon nanotubes following inhalation and intratracheal instillation. Nanotoxicology 2012, 6, 587-599. [CrossRef]

18. Morimoto, Y.; Izumi, H.; Kuroda, E. Significance of Persistent Inflammation in Respiratory Disorders Induced by Nanoparticles. J. Immunol. Res. 2014. [CrossRef] [PubMed]

19. Morimoto, Y.; Izumi, H.; Yoshiura, Y.; Tomonaga, T.; Lee, B.W.; Okada, T.; Oyabu, T.; Myojo, T.; Kawai, K.; Yatera, K.; et al. Comparison of pulmonary inflammatory responses following intratracheal instillation and inhalation of nanoparticles. Nanotoxicology 2016, 10, 607-618. [CrossRef]

20. Morimoto, Y.; Izumi, H.; Yoshiura, Y.; Tomonaga, T.; Oyabu, T.; Myojo, T.; Kawai, K.; Yatera, K.; Shimada, M.; Kubo, M.; et al. Pulmonary toxicity of well-dispersed cerium oxide nanoparticles following intratracheal instillation and inhalation. J. Nanoparticle Res. 2015, 17, 1-16. [CrossRef]

21. Morimoto, Y.; Izumi, H.; Yoshiura, Y.; Tomonaga, T.; Oyabu, T.; Myojo, T.; Kawai, K.; Yatera, K.; Shimada, M.; Kubo, M.; et al. Evaluation of pulmonary toxicity of zinc oxide nanoparticles following inhalation and intratracheal instillation. Int. J. Mol. Sci. 2016, 17, 1241. [CrossRef]

22. Keller, J.; Wohlleben, W.; Ma-Hock, L.; Strauss, V.; Gröters, S.; Küttler, K.; Wiench, K.; Herden, C.; Oberdörster, G.; van Ravenzwaay, B.; et al. Time course of lung retention and toxicity of inhaled particles: Short-term exposure to nano-Ceria. Arch. Toxicol. 2014, 88, 2033-2059. [CrossRef] 
23. Cho, W.-S.; Duffin, R.; Howie, S.E.M.; Scotton, C.J.; Wallace, W.A.H.; MacNee, W.; Bradley, M.; Megson, I.L.; Donaldson, K. Progressive severe lung injury by zinc oxide nanoparticles; the role of Zn2+ dissolution inside lysosomes. Part. Fibre Toxicol. 2011, 8, 27. [CrossRef]

24. Oyabu, T.; Myojo, T.; Lee, B.W.; Okada, T.; Izumi, H.; Yoshiura, Y.; Tomonaga, T.; Li, Y.S.; Kawai, K.; Shimada, M.; et al. Biopersistence of $\mathrm{NiO}$ and $\mathrm{TiO}_{2}$ nanoparticles following intratracheal instillation and inhalation. Int. J. Mol. Sci. 2017, 18, 2757. [CrossRef]

25. Dunnick, J.K.; Elwell, M.R.; Radovsky, A.E.; Benson, J.M.; Hahn, F.F.; Nikula, K.J.; Barr, E.B.; Hobbs, C.H. Comparative Carcinogenic Effects of Nickel Subsulfide, Nickel Oxide, or Nickel Sulfate Hexahydrate Chronic Exposures in the Lung. Cancer Res. 1995, 55, 5251-5256. [PubMed]

26. Ma, J.Y.C.; Young, S.-H.; Mercer, R.R.; Barger, M.; Schwegler-Berry, D.; Ma, J.K.; Castranova, V. Interactive effects of cerium oxide and diesel exhaust nanoparticles on inducing pulmonary fibrosis HHS Public Access. Toxicol. Appl. Pharmacol. 2014, 278, 135-147. [CrossRef] [PubMed]

27. Yoshiura, Y.; Izumi, H.; Oyabu, T.; Hashiba, M.; Kambara, T.; Mizuguchi, Y.; Lee, B.W.; Okada, T.; Tomonaga, T.; Myojo, T.; et al. Pulmonary toxicity of well-dispersed titanium dioxide nanoparticles following intratracheal instillation. J. Nanoparticle Res. 2015, 17, 241. [CrossRef] [PubMed]

28. Kobayashi, N.; Naya, M.; Endoh, S.; Maru, J.; Yamamoto, K.; Nakanishi, J. Comparative pulmonary toxicity study of nano-TiO2 particles of different sizes and agglomerations in rats: Different short- and long-term post-instillation results. Toxicology 2009, 264, 110-118. [CrossRef]

29. Adamcakova-Dodd, A.; Stebounova, L.V.; Kim, J.S.; Vorrink, S.U.; Ault, A.P.; O'Shaughnessy, P.T.; Grassian, V.H.; Thorne, P.S. Toxicity assessment of zinc oxide nanoparticles using sub-acute and sub-chronic murine inhalation models. Part. Fibre Toxicol. 2014, 11, 15. [CrossRef]

30. TORAY. 3D-Gene@. Available online: https://www.3d-gene.com/en/\#/ (accessed on 28 May 2020).

31. DAVID. Functional Annotation Bioinformatics Microarray Analysis. Available online: https://david.ncifcrf. gov/(accessed on 28 May 2020).

32. Sasaki, S.; Izumi, H.; Morimoto, Y.; Sakurai, K.; Mochizuki, S. Induction of potent cell growth inhibition by schizophyllan/K-ras antisense complex in combination with gemcitabine. Bioorganic Med. Chem. 2020, 28, 115668. [CrossRef]

33. Johnston, B.; Butcher, E.C. Chemokines in rapid leukocyte adhesion triggering and migration. Semin. Immunol. 2002, 14, 83-92. [CrossRef]

34. Gasperini, S.; Marchi, M.; Calzetti, F.; Laudanna, C.; Vicentini, L.; Olsen, H.; Murphy, M.; Liao, F.; Farber, J.; Marco, C.A. Gene expression and production of the monokine induced by IFN-gamma (MIG), IFN-inducible T cell alpha chemoattractant (I-TAC), and IFN-gamma-inducible protein-10 (IP-10) chemokines by human neutrophils. J. Immunol. 1999, 162, 4928-4937. [PubMed]

35. Hildebrandt, G.C.; Corrion, L.A.; Olkiewicz, K.M.; Lu, B.; Lowler, K.; Duffner, U.A.; Moore, B.B.; Kuziel, W.A.; Liu, C.; Cooke, K.R. Blockade of CXCR3 Receptor: Ligand Interactions Reduces Leukocyte Recruitment to the Lung and the Severity of Experimental Idiopathic Pneumonia Syndrome. J. Immunol. 2004, 173, 2050-2059. [CrossRef] [PubMed]

36. Takaku, Y.; Soma, T.; Uchida, Y.; Kobayashi, T.; Nakagome, K.; Nagata, M. CXC chemokine superfamily induced by Interferon- $\gamma$ in asthma: A cross-sectional observational study. Asthma Res. Pract. 2016, 2, 6. [CrossRef] [PubMed]

37. Jeyaseelan, S.; Manzer, R.; Young, S.K.; Yamamoto, M.; Akira, S.; Mason, R.J.; Worthen, G.S. Induction of CXCL5 during inflammation in the rodent lung involves activation of alveolar epithelium. Am. J. Respir. Cell Mol. Biol. 2005, 32, 531-539. [CrossRef]

38. Fujita, K.; Fukuda, M.; Fukui, H.; Horie, M.; Endoh, S.; Uchida, K.; Shichiri, M.; Morimoto, Y.; Ogami, A.; Iwahashi, H. Intratracheal instillation of single-wall carbon nanotubes in the rat lung induces time-dependent changes in gene expression. Nanotoxicology 2015, 9, 290-301. [CrossRef]

39. Oh, J.H.; Yang, M.J.; Yang, Y.S.; Park, H.J.; Heo, S.H.; Lee, E.H.; Song, C.W.; Yoon, S. Microarray-based analysis of the lung recovery process after stainless-steel welding fume exposure in Sprague-Dawley rats. Inhal. Toxicol. 2009, 21, 347-373. [CrossRef]

40. Balamayooran, G.; Batra, S.; Cai, S.; Mei, J.; Worthen, G.S.; Penn, A.L.; Jeyaseelan, S. Role of CXCL5 in leukocyte recruitment to the lungs during secondhand smoke exposure. Am. J. Respir. Cell Mol. Biol. 2012, 47, 104-111. [CrossRef] 
41. Fujita, K.; Morimoto, Y.; Endoh, S.; Uchida, K.; Fukui, H.; Ogami, A.; Tanaka, I.; Horie, M.; Yoshida, Y.; Iwahashi, H.; et al. Identification of potential biomarkers from gene expression profiles in rat lungs intratracheally instilled with C60 fullerenes. Toxicology 2010, 274, 34-41. [CrossRef]

42. Proost, P.; Wuyts, A.; van Damme, J. Human monocyte chemotactic proteins-2 and -3: Structural and functional comparison with MCP-1. J. Leukoc. Biol. 1996, 59, 67-74. [CrossRef]

43. Langley, R.J.; Mishra, N.C.; Peña-Philippides, J.C.; Rice, B.J.; Seagrave, J.C.; Singh, S.P.; Sopori, M.L. Fibrogenic and redox-related but not proinflammatory genes are upregulated in Lewis rat model of chronic silicosis. J. Toxicol. Environ. Heal. Part A 2011, 74, 1261-1279. [CrossRef]

44. Fujita, K.; Fukuda, M.; Endoh, S.; Maru, J.; Kato, H.; Nakamura, A.; Shinohara, N.; Uchino, K.; Honda, K. Pulmonary and pleural inflammation after intratracheal instillation of short single-walled and multi-walled carbon nanotubes. Toxicol. Lett. 2016, 257, 23-37. [CrossRef]

45. Abdelgied, M.; El-Gazzar, A.M.; Alexander, D.B.; Alexander, W.T.; Numano, T.; Iigou, M.; Naiki-Ito, A.; Takase, H.; Abdou, K.A.; Hirose, A.; et al. Potassium octatitanate fibers induce persistent lung and pleural injury and are possibly carcinogenic in male Fischer 344 rats. Cancer Sci. 2018, 109, 2164-2177. [CrossRef]

46. Belperio, J.A.; Keane, M.P.; Burdick, M.D.; Lynch, J.P.; Xue, Y.Y.; Li, K.; Ross, D.J.; Strieter, R.M. Critical role for CXCR3 chemokine biology in the pathogenesis of bronchiolitis obliterans syndrome. J. Immunol. 2002, 169, 1037-1049. [CrossRef] [PubMed]

47. Oyabu, T.; Morimoto, Y.; Hirohashi, M.; Horie, M.; Kambara, T.; Lee, B.W.; Hashiba, M.; Mizuguchi, Y.; Myojo, T.; Kuroda, E. Dose-dependent pulmonary response of well-dispersed titanium dioxide nanoparticles following intratracheal instillation. J. Nanoparticle Res. 2013, 15. [CrossRef]

48. Morrow, P.E.; Muhle, H.; Mermelstein, R. Chronic Inhalation Study Findings as a Basis for Proposing a New Occupational Dust Exposure Limit. J. Am. Coll. Toxicol. 1991, 10, 279-290. [CrossRef]

49. Bellmann, B.; Muhle, H.; Creutzenberg, O.; Mermelstein, R. Irreversible pulmonary changes induced in rat lung by dust overload. Environ. Heal. Perspect. 1992, 97, 189-191. [CrossRef] [PubMed]

50. Thiefes, A.; Wolter, S.; Mushinski, J.F.; Hoffmann, E.; Dittrich-Breiholz, O.; Graue, N.; Dörrie, A.; Schneider, H.; Wirth, D.; Luckow, B.; et al. Simultaneous blockade of NFKB, JNK, and p38 MAPK by a kinase-inactive mutant of the protein kinase TAK1 sensitizes cells to apoptosis and affects a distinct spectrum of tumor necrosis target genes. J. Biol. Chem. 2005, 280, 27728-27741. [CrossRef] [PubMed]

51. Li, J.; Liang, C.; Zhang, Z.K.; Pan, X.; Peng, S.; Lee, W.S.; Lu, A.; Lin, Z.; Zhang, G.; Leung, W.N.; et al. TAK1 inhibition attenuates both inflammation and fibrosis in experimental pneumoconiosis. Cell Discov. 2017, 3, 1-21. [CrossRef]

Publisher's Note: MDPI stays neutral with regard to jurisdictional claims in published maps and institutional affiliations.

(C) 2020 by the authors. Licensee MDPI, Basel, Switzerland. This article is an open access article distributed under the terms and conditions of the Creative Commons Attribution (CC BY) license (http://creativecommons.org/licenses/by/4.0/). 